Document downloaded from:

http://hdl.handle.net/10251/105860

This paper must be cited as:

Zambrano Mera, YE.; Rivadeneira Vera, JF.; Pérez-Martín, MÁ. (2018). Linking El Niño Southern Oscillation for early drought detection in tropical climates: The Ecuadorian coast. The Science of The Total Environment. 643:193-207. doi:10.1016/j.scitotenv.2018.06.160

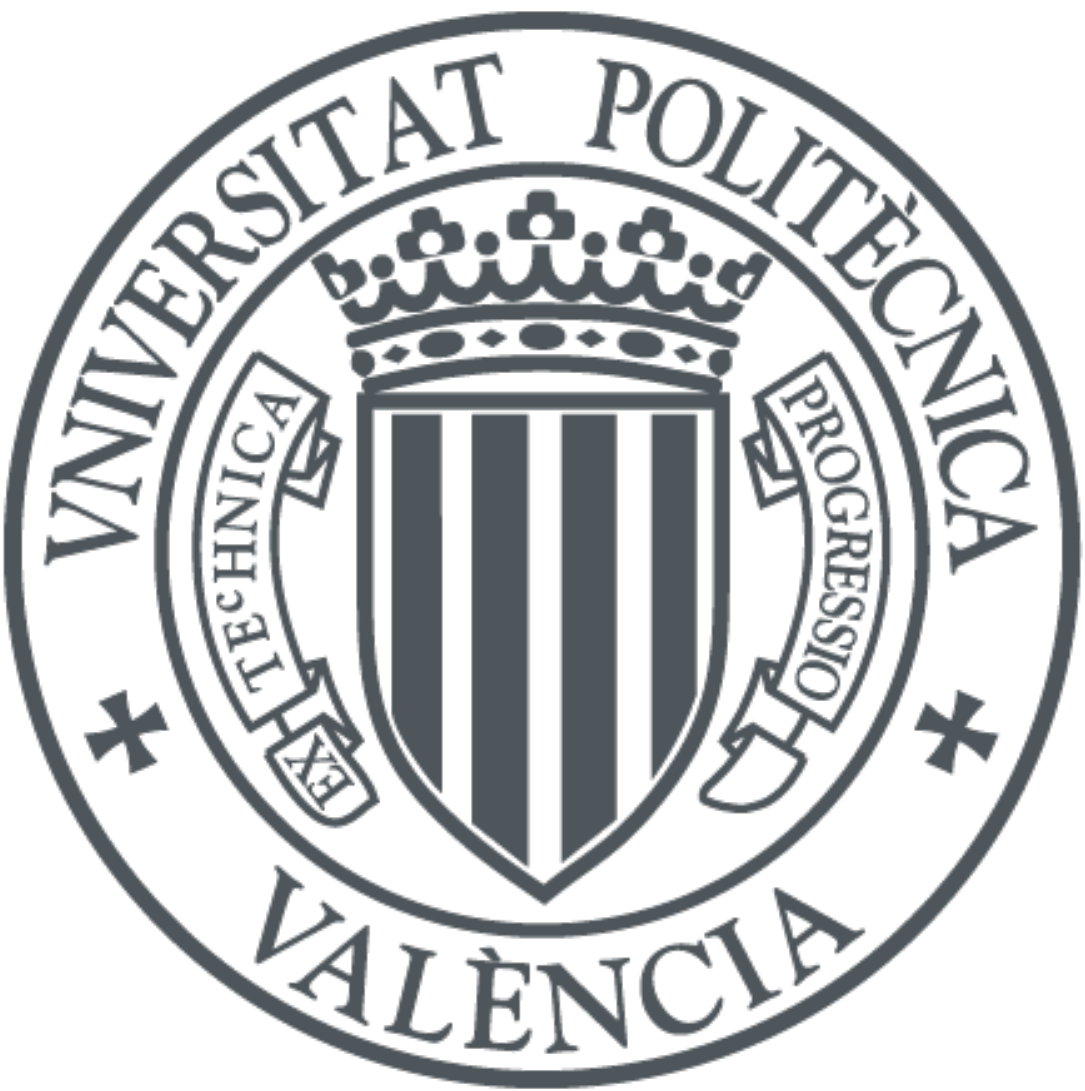

The final publication is available at

https://doi.org/10.1016/j.scitotenv.2018.06.160

Copyright Elsevier

Additional Information 


\section{Linking EI Niño Southern Oscillation for early drought detection in tropical climates: The Ecuadorian coast}

\section{Author names and affiliations:}

Yeriel Elizabeth Zambrano Mera ${ }^{\mathrm{a}, *}$, Jonny Fernando Rivadeneira Vera ${ }^{\mathrm{a}}$ and Miguel Ángel Pérez-Martín ${ }^{\mathrm{a}}$.

${ }^{a}$ Research Institute of Water and Environmental Engineering (IIAMA), Universitàt Politècnica de València Camino de Vera, s/n, Valencia, ES 46022

* Corresponding Author: yezamme@posgrado.upv.es $\stackrel{+34673478802}{2}$ 
El Niño Southern Oscillation (ENSO) is the most determining climate pattern in the tropics of the Pacific coast of America that regulate flood and drought periods. Over the last decades, Ecuador has incurred in significant economic losses due to drought events, around $4 \%$ of the GDP, mainly in the agricultural and livestock sectors and the hydropower generation. The use of Drought Indicators and the Early Drought Detection can contribute to reduce the impacts of these events. A drought forecasting system, based on ENSO and Drought Indicators, is presented to determine the possibility of appearance of drought events in Manabí River Basin District (MRBD). This system can help to the decision makers, in December (short-term drought, seasonal) and in May (long-term drought, annual), to activate the drought measures in the following months.

Six climate indices are used for ENSO: Oceanic Niño Index (ONI), Southern Oscillation Index (SOI), and Sea Surface Temperature (SST) for Niño regions: 4, 3.4, 3 and $1+2$. On the other hand, two drought indices are used: spatially distributed Standardized Precipitation Index (SPI) -1, 3, 6 and 12 months-, and a modified Palmer Drought Severity Index (PDSI), derived from a calibrated water balance model.

This system allows early drought detection, assessing SST 1+2 (lag -7), 3 (lag 9) and 3.4 (lag -9) anomalies and drought indices, in December for a season drought and May for an annual drought. These analyses demonstrates that, drought may forecasting up to seven - nine months before their occurrence, through SST regions observations, based on strong relationship between ENSO and droughts occurrence.

Keywords:

Early Drought Detection, Droughts indicators, Drought Management, ENSO, Tropical climate, SST Niño regions. 


\section{Introduction}

The tropical atmosphere is characterized by high temperatures and humidity (Hastenrath, 1985). Rain is probably the most varying element in tropical climates. Three general sub-climatic regions can be distinguished: humid ( $>1800 \mathrm{~mm})$, humid-dry $(700-1800 \mathrm{~mm})$ and dry $(<700 \mathrm{~mm})$. Humid tropical climates are characterized by temperatures ranging from 24 to $30^{\circ} \mathrm{C}$, with annual fluctuations of approximately $3{ }^{\circ} \mathrm{C}$, whereas dry tropical climates have higher temperatures as a consequence of the intense radiation on the earth surface. Three typical humid-dry climatic regions in South America are: El Cerrado, Llanos and Chaco. Geographically, tropical regions are more or less demarcated by the Tropics of Cancer $\left(23^{\circ} 27^{\prime} \mathrm{N}\right)$ and Capricorn $\left(23^{\circ} 27^{\prime} \mathrm{S}\right)$. Sun angles are high, and therefore, there is only a diurnal variation of 12 to $13 \mathrm{~h}$. Solar radiation affects the hydrological cycle, more directly in the tropics than in other regions of the planet (Latrubesse et al., 2005).

El Niño Southern Oscillation (ENSO) events are usually linked to major flood and drought episodes (Barlow et al., 2001). These extreme hydrometeorological events have the potential to cause devastating impacts on humans and the environment (Gómez-Martínez et al., 2018; Pielke and Landsea, 1999). Several studies have been carried out to find the relationship between ENSO events and droughts, for example, (Wang and Kumar, 2015) found a strong relationship between the southwestern US drought and La Niña during the period 1948-1977, and between southwestern precipitations and El Niño during the period 1978-1999, reaching the conclusion that ENSO can alter precipitation patterns, and therefore, affect southwestern droughts in terms of frequency and intensity. A study carried out in the Sonoran desert, from May to September 2000-2015 (Zolotokrylin et al., 2016), indicates that the probability of wet conditions between May-September was incremented following El Niño and La Niña or 
the setting of La Niña conditions. Likewise (Verbist et al., 2010) concluded that the Coquimbo region, located to the North of Chile, is under a strong influence of El Niño, with a reported precipitation increase during hot weather episodes. However, most of the influence of ENSO on droughts is caused by a decrease in precipitation associated with La Niña (Meza, 2013).

A drought is a natural phenomenon that affects humans much more severely than any other natural events (FAO, 2013). It is ranked first among the natural dangers affecting agriculture, water resources, ecology, and society (Mishra and Singh, 2010). The effects of droughts can vary on an extensive scale, depending on the type of drought and people's vulnerability (Wong et al., 2013). Drought frequency in many countries reduces GDP growth and threatens social development goals (Shiferaw et al., 2014). Over the last decades, Ecuador has incurred losses of more than US\$ 4 billion due to drought events (World Food Programme, 2011). In November 2009, dry climatic conditions were reported in the coastal regions of Ecuador (Baringer et al., 2010), mainly affecting the province of Manabí and causing substantial losses in the agricultural sector. Losses have been estimated to have reached US\$ 262 million, without taking into account the livestock sector due to the lack of information (Climate, Energy and Tenure Division, Deputy Directory-General Natural Resources, 2010).

The drought early detection helps to implement drought mitigation strategies and measures before they occur (Barua et al., 2015). Reassignment of water resources in a reasonable way allow mitigate the loss of agricultural products due to the drought (Haile, 2005).

Impacts associated with drought have contributed to trend toward improved drought preparedness and policy development (Wilhite et al., 2005). Drought preparedness, and the policies which facilitate its implementation, can increase adaptive 
capacity and resilience of water resources management (Engle, 2013). The characteristics that constitute effective drought preparedness are different depending on the scale at which one is evaluating it, as well as the sector of interest (Gutiérrez et al., 2014). A methodology developed by (Wilhite, 1991) and revised to incorporate greater emphasis on risk management (Wilhite et al., 2000) has provided a set of guidelines or a checklist of the key elements to facilitating the preparation of drought contingency plans which they can be adapted to any level of government. Drought preparedness include three basic categories; monitoring and early warning, vulnerability and impact assessments, and mitigation and response planning and measures (Wilhite et al., 2005). Estrela and Vargas, (2012), are highlight the link between the national drought indicator system and the actions to be taken in the drought management plans developed in Spain, show that, they represent strategic tools with positive results in drought warning and impact mitigation respectively.

To limit the adverse impacts of drought are useful structural and non-structural measures e.g., strategic, tactical and emergency measures are use in Spain (CHJ, 2007). Strategic measures are long-term actions of an institutional and infrastructural nature, tactical measures are short-term actions and are intended to conserve resources through improvements in management, joint use of surface and groundwater and voluntary savings in large consumer units. Emergency measures are activated in a state of emergency and are intended to extend the available resources as long as possible, so it is necessary to establish restrictions to lower priority uses and even generalize restrictions in advanced phases. Among structural measures is useful to use e.g., rain-fed water cisterns construction, building dams, aqueducts and pumping stations (Gutiérrez et al., 2014), floodplain storages (De Martino et al., 2012), stormwater capture tanks (Paola et al., 2013). Freshwater systems much of the world will experience significant stress as a 
result of climate change, (Kundzewicz et al., 2007) to cope with this, is useful to use measures eg., De Paola et al., (2015).

Drought does not appear to have a universal definition. (Mishra and Singh, 2010) provide a thorough review on the concept of drought. Various indices have been developed to quantify droughts, some examples of such indices are: The Palmer Drought Severity Index PDSI (Wayne C. Palmer, 1965); Rainfall Anomaly Index (RAI) (Van Rooy, 1965); Deciles (Gibbs and Maher, 1967); Crop Moisture Index (CMI) (Palmer, 1968); Bhalme and Mooly drought index (BMDI) (Bhalme and Mooley, 1980); Surface Water Supply Index (SWSI) (Shafer and Dezman, 1982); National Rainfall Index (NRI) (Gommes and Petrassi, 1996). Standardized Precipitation Index (SPI) (McKee et al., 1995); and Reclamation Drought Index (RDI) (Weghorst, 1996); The Soil Moisture Drought Index (SMDI) (Hollinger et al., 1993); and Crop-Specific Drought Index (CSDI) (Meyer and Hubbard, 1995) appeared after CMI. Furthermore, CSDI is divided into a Corn Drought Index (CDI) (Meyer and Pulliam, 1992) and Soybean Drought Index (SDI) (Meyer and Hubbard, 1995); Vegetation Condition Index (VCI) (Liu and Kogan, 1996). In addition to the aforementioned indicators, indices of Penman, 1948; Thornthwaite, 1948; and Keetch and Byram, 1968, have been used in limited cases (Hayes, 1996). A new index has been developed for evaluating drought: The Standardized Precipitation Evapotranspiration Index (SPEI) (Vicente-Serrano et al., 2009). The self-calibrating Palmer Drought Severity Index (scPDSI) was likewise developed for comparing dry regions with varying drought conditions (Wells et al., 2004). In Spain, an index called Status Index (SI) has been adopted for monitoring operational droughts in hydrological systems (CHJ, 2007; Ortega-Gómez et al., 2018). The most common drought indices are: PDSI, Deciles, CMI, SWSI, SPI or RDI (PedroMonzonís et al., 2015). 
There is a significant interest in using climate indices for long-term forecasting of regional droughts (Vicente-Serrano et al., 2016). The objective of this research was, therefore, to establish a drought forecasting system, based on ENSO and Drought Indicators in the tropical climate of Manabí River Basin District (MRBD). To characterize the drought was using the Standardized Precipitation Index (SPI) and Palmer Drought Severity Index (PDSI). Indices values were validated through press releases addressing droughts in the study area. We correlated the Southern Oscillation Index (SOI), Oceanic Niño Index (ONI), Sea Surface Temperature (SST), and the drought indices SPI and PDSI for estimating the relationship between ENSO events and drought occurrence in the MRBD.

The paper is structured in: Section 2, describing the methodology and data set used in the study; Section 3 presenting the results and discussion, with a special emphasis on the early drought detection based on ENSO and drought indicators; followed by the conclusions in Section 4. 


\section{Methodology and dataset}

In this study, we used the historical precipitation and temperature series (Oct.1964 Sep.2012) to obtain the historical series of drought indices SPI and PDSI and to identify drought occurrence in the MRBD during the same period. Index results were validated with the historical press releases shown in Table 1, available in the Disaster Inventory System (DesInventar in Spanish) from OSSO Corporation - Colombia (https://online.desinventar.org). DesInventar is a conceptual and methodological tool for database creation on losses, damages and impacts caused by emergencies or disasters.

\begin{tabular}{ccccc}
\hline Event & Date & Zone & Affected Sector & Record \\
\hline \hline Drought & $03 / 82$ & Central and South & Agricultural and livestock & $02 / 80-03 / 82$ \\
El Niño (flood) & $08 / 83$ & North, Central and South & Agricultural and livestock & $12 / 82-08 / 83$ \\
Drought & $05 / 90$ & Central & Agricultural and livestock & $02 / 90-05 / 90$ \\
Drought & $07 / 91$ & Central & Agricultural, livestock and industriall & $01 / 91-07 / 91$ \\
Drought & $01 / 97$ & North and Central & Agricultural and livestock & $01 / 96-01 / 97$ \\
El Niño (flood) & $08 / 98$ & North, Central and South & Agricultural and livestock & $12 / 97-08 / 98$ \\
Drought & $01 / 02$ & North & Agricultural and livestock & $11 / 01-01 / 02$ \\
Drought & $03 / 06$ & Central and South & Agricultural and livestock & $05 / 05-03 / 06$ \\
Drought & $12 / 09$ & North, Central and South & Agricultural and livestock & $09 / 09-12 / 09$ \\
\hline
\end{tabular}

Table 1.- Records of press releases addressing drought episodes from 1982 to 2012.

Once the SPI values were obtained at multiple scales, and the PDSI were generated, it was possible to determine the correlation between drought occurrence and El Niño Southern Oscillation (an interannual oceanic-atmospherical oscillation in the tropical Pacific Ocean) (Trenberth et al., 2015), with two phases: El Niño and La Niña. Both are opposing climate episodes that are characterized by the unusual warming and cooling of surface ocean waters (Lee and Julien, 2016).

For detecting the influence of ENSO events on precipitation patterns in the MRDB, we used the Sea Surface Temperature (SST) data series for Niño regions from January 1982 to September 2012; the Oceanic Niño Index (ONI) data series and the South Oscillation Index, from October 1964 to September 2012. Data were obtained from the National Centres for Environmental Information (NCEI) webpage, and from 
http://www.ncdc.noaa.gov/teleconnections/enso. A flow diagram is shown in Figure 1.

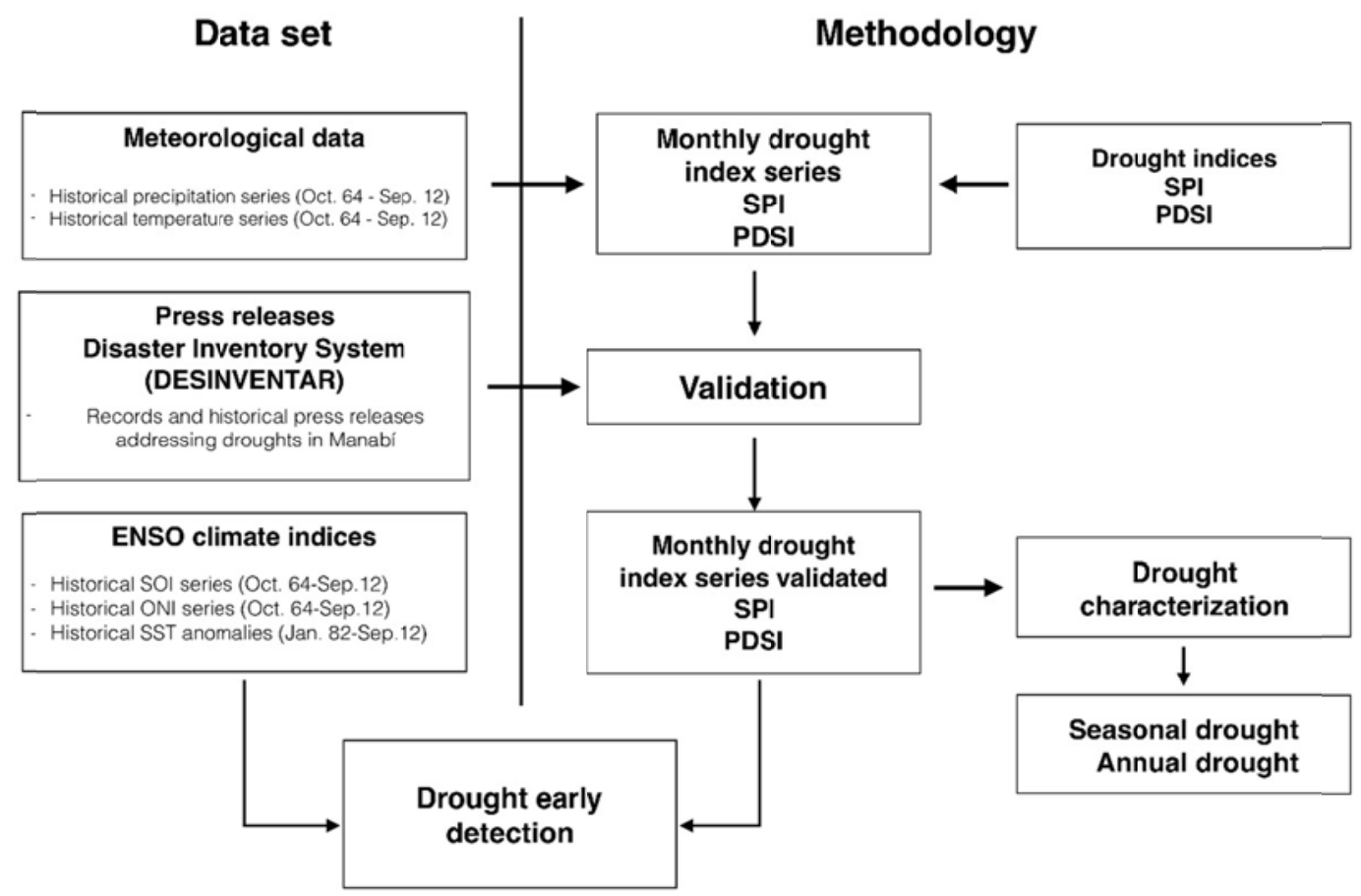

Figure 1.- Methodology to early drought detection

To understand the development of the events El Niño/La Niña in the ENSO cycle along the Equatorial Pacific Ocean, 4 regions have been defined: Niño $4\left(150^{\circ} \mathrm{O}-\right.$ $160^{\circ} \mathrm{E}$ and $\left.5^{\circ} \mathrm{N}-5^{\circ} \mathrm{S}\right)$; Niño $3.4\left(120^{\circ} \mathrm{O}-170^{\circ} \mathrm{O}\right.$ and $\left.5^{\circ} \mathrm{N}-5^{\circ} \mathrm{S}\right)$; Niño $3\left(90^{\circ} \mathrm{O}-150^{\circ} \mathrm{O}\right.$ and $\left.5^{\circ} \mathrm{N}-5^{\circ} \mathrm{S}\right)$ and Niño $1+2\left(90^{\circ} \mathrm{O}-80^{\circ} \mathrm{O}\right.$ and $\left.0^{\circ}-10^{\circ} \mathrm{S}\right)$ encompassing the coasts of Peru and Ecuador. For analysis, Pearson's r correlation and cross-correlation (Díaz and Manuel, 2014) were used. The correlation analysis considered the SPI (3, 6, 12 months), the monthly PDSI and the climate indices ONI, SOI y SST (Niño 4, 3.4, 3 and 1+2) for the north, central and south zones of the MRBD from the year 1982, due to data availability.

The monthly precipitation and temperature data series in this research were obtained from 89 stations distributed along the province of Manabí-Ecuador. $25 \%$ of the data corresponded to a collection for a period of more than 30 years. The source of the 
data was the National Meteorological and Hydrological Institute (INAMHI in Spanish), a government research institute affiliated with the National Secretariat for Risk Management of Ecuador, dealing with general climate monitoring and control. The precipitation and temperature data series corresponded to the 1964-2012 period (Fig. 2). These series were inserted in the distributed model PATRICAL (Pérez-Martín et al., 2014) with the objective of obtaining special climate information of the basin district for use according to the area of interest. Figure 2a shows that between 1964 and 2012, the annual average precipitation in the MRBD was $995 \mathrm{~mm}$.

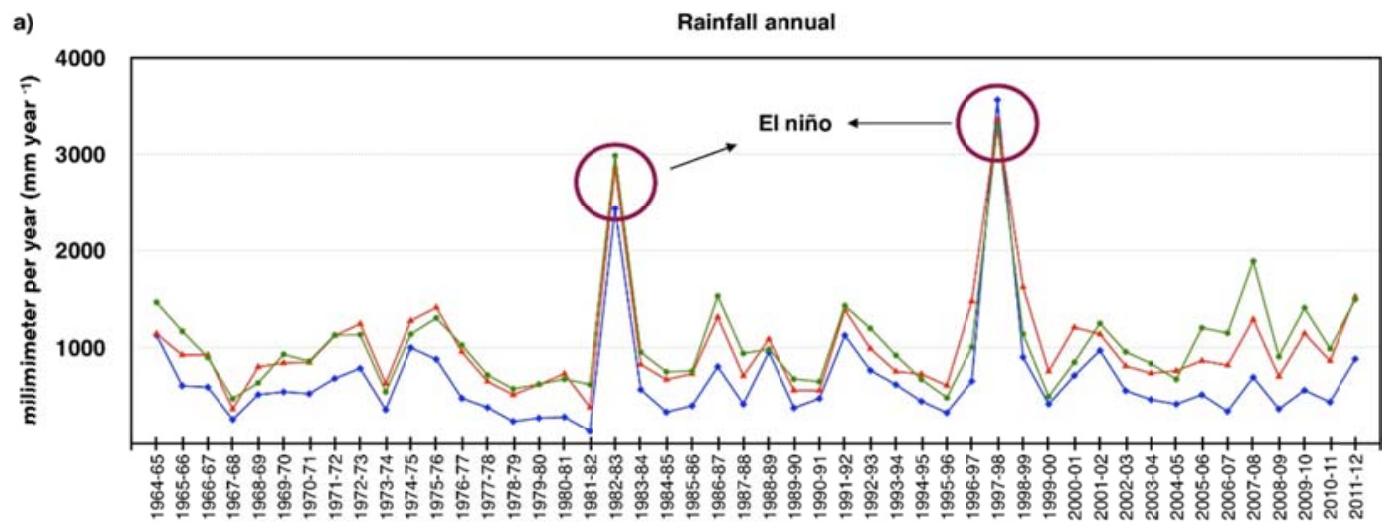

b)

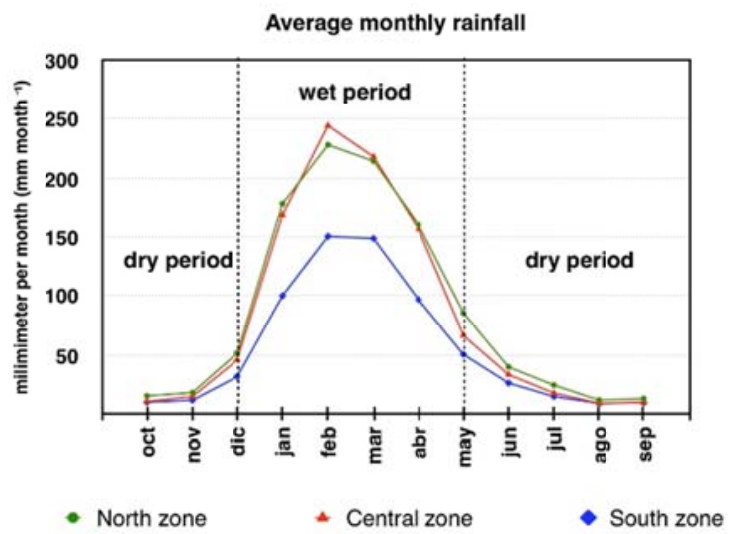

Figure 2.- a) Historical annual precipitations emphasizing ENSO events during El Niñno phase, 1982-83 and 1997-98. b) Monthly average precipitations in the north, central and south zones of the MRBD.

The highest annual precipitation level was registered in the 1982/83, with 2855 mm and 1997/98 with $3352 \mathrm{~mm}$, as a consequence of the ENSO event during El Niño phase (Bell et al., 1999), (D’Ercole and Trujillo, 2003). The lowest precipitation level was registered in 1967/68 with $353 \mathrm{~mm}$. In a normal year, annual average precipitation 
reaches $903 \mathrm{~mm}$. The MRBD has two seasons (Fig. 2b): wet (DEFMAM) and dry (JJASON), very common for a tropical climate. The wet and dry seasons have monthly average precipitations of $196 \mathrm{~mm}$ and $19 \mathrm{~mm}$, respectively.

\subsection{Study area}

The Manabí River Basin District is located in the west of Ecuador in three of its 24 provinces, with Manabí as the province with the largest territory comprising $97.7 \%$ of the area. The basin district is formed by 17 hydrographic basins, with an area of 11,483 $\mathrm{km}^{2}$ and an approximate population of 1.15 million inhabitants, representing $8 \%$ of the total Ecuadorian population. From west to east, it has three types of transverse extension tropical climates: semiarid megathermal climate, dry/sub-humid megathermal climate and humid megathermal climate (Pourrut, 1983; Ríos and Josefina, 2016).

In this study, the MRBD was divided into three zones (Fig. 3), named according to their geographical location: North Zone (NZ), Central Zone (CZ) and South Zone (SZ), with an area of $3265 \mathrm{~km}^{2}, 5331 \mathrm{~km}^{2}$ and $2702 \mathrm{~km}^{2}$, respectively. In the NZ and $\mathrm{CZ}$, the predominant climates are the dry/sub-humid megathermal climate and the humid megathermal climate, whereas the SZ is dominated by a semiarid megathermal climate. The $\mathrm{CZ}$ is the most representative region because it has the main hydrological infrastructures in the basin district, and because it has the two largest basins: The Chone River Basin and Portoviejo River Basin. In the Chone river basin, we studied the Carrizal river subbasin, and in the Portoviejo river basin, we studied the headwaters of the Portoviejo river and the Chico river subbasin. 


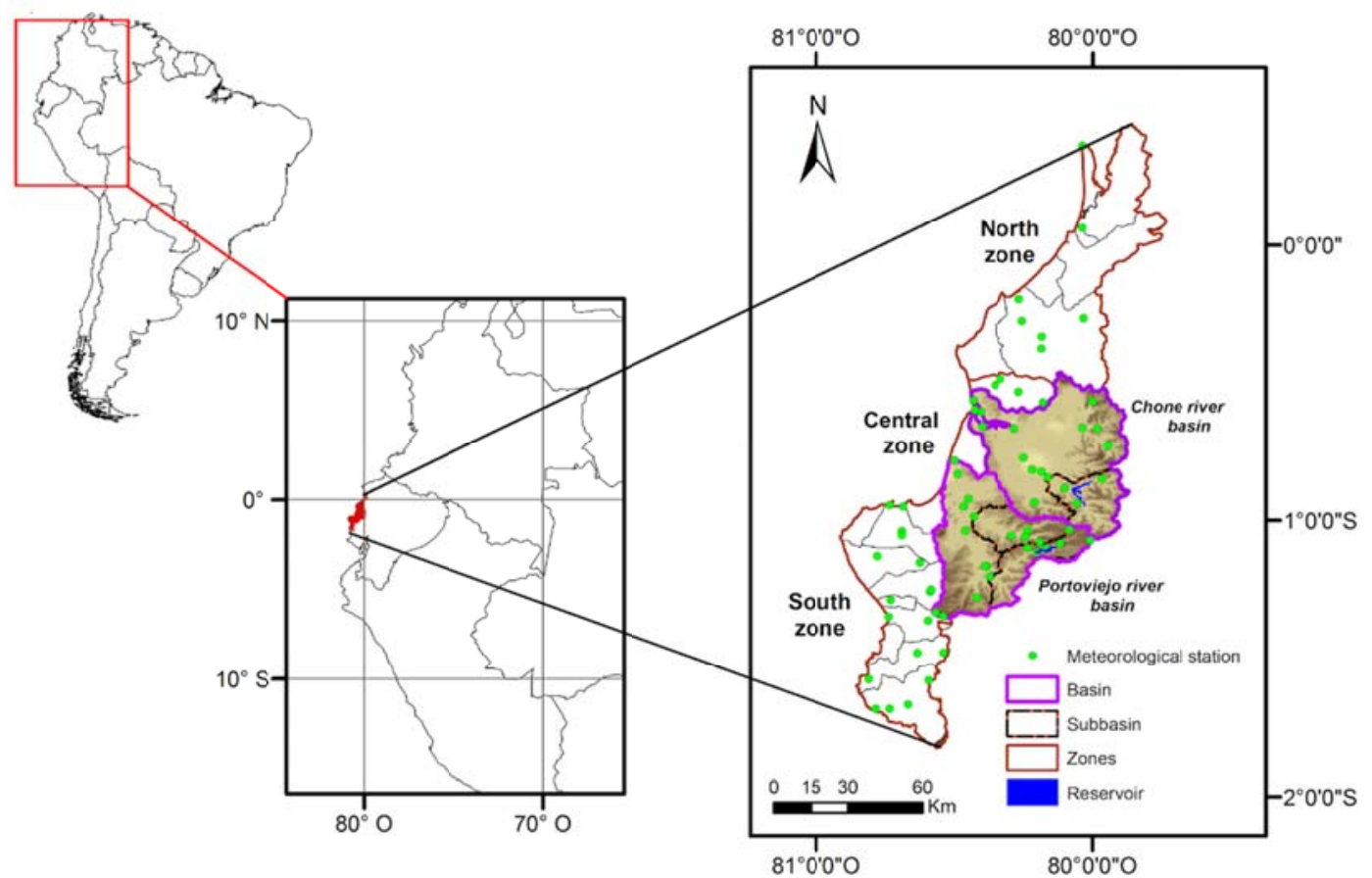

Figure 3.- Study area, Manabi River Basin District, located at $79^{\circ} 50^{\prime} 00^{\prime \prime} \mathrm{O}-82^{\circ} 00^{\prime} 00^{\prime \prime} \mathrm{O}$ and $0^{\circ} 50^{\prime} 00^{\prime \prime} \mathrm{N}$ $-2^{\circ} 00^{\prime} 00^{\prime} \mathrm{S}$, in the west of Ecuador. 


\subsection{Drought indices}

We used the Standardized Precipitation Index (SPI) for estimating precipitation deficit at multiple timescales $(3,6,12,24,48$ months). SPI calculations, for a given place, were based on a long-term precipitation record for a specific period. This long-term record was adjusted to a probability distribution, which was later transformed into a normal distribution so that average SPI values for a given location and time become zero (Edwards and McKee, 1997). For this study, we calculated SPI for 3,6,12 and 24 months through the equation proposed by McKee et al., 1995.

After considering the magnitude of the calculations (5 timescales and 3 study areas), we decided to use the SPI_SL_6 software, created by the National Drought Mitigation Centre of the University of Nebraska-Lincoln. Prior to that, it was necessary to calculate SPI at 1 month using the abovementioned equation for correlation analysis with SPI-1 obtained from the software, because the software adjusts the historical precipitation series to the gamma distribution. We obtained a high positive correlation of 0.95 . Drought events in the MRBD were determined according to the classification system by McKee et al., 1995 (Table 2).

\begin{tabular}{rc|rr}
\hline \multicolumn{4}{c}{ Classification of drought } \\
\hline \hline SPI Drought Category & $\begin{array}{c}\text { SPI value } \\
\text { (McKee et al., 1993) }\end{array}$ & PDSI Drought Category & $\begin{array}{r}\text { PDSI value (W. C. } \\
\text { Palmer, 1965) }\end{array}$ \\
\hline \hline Extremely wet & 2.00 and above & Extremely wet & Above 4.00 \\
Very wet & 1.50 to 1.99 & Very wet & 3.00 to 3.99 \\
Moderately wet & 1.00 to 1.49 & Moderate wet & 2.00 to 2.99 \\
& & slightly wet & 1.00 to 1.99 \\
Near normal & -0.99 to 0.99 & Incipient wet spell & 0.50 to 0.99 \\
& & Near normal & 0.49 to -0.49 \\
Moderately dry & -1.00 to -1.49 & Incipient drought & -0.50 to -0.99 \\
Severely dry & -1.50 to -1.99 & Mild drought & -1.00 to -1.99 \\
Extremely dry & -2.00 and less & Moderate drought & -2.00 to -2.99 \\
\hline \hline
\end{tabular}

Table 2.- Drought classification criteria for SPI (McKee et al., 1993) and PDSI (Palmer, 1965). 
The Palmer Drought Severity Index (PDSI) was used for measuring the state of moisture supply. It was calculated from the water balance model, taking into account more than the precipitation deficit at a given location (Wayne C. Palmer, 1965). Palmer defined Climatologically Appropriate for Existing Conditions (CAFEC) values for normalizing calculations so that, dimensionally, the index can be compared over time and space. In the water balance calculations, we estimated the potential evapotranspiration, recharge, runoff and coefficients for each parameter, which were obtained from a quotient between actual and potential values.

For PDSI estimation, we used the two formulations proposed by Palmer, 1965 for potential runoff estimation (PRO). Palmer defines PRO as the Available Water Capacity (AWC) minus the Potential Recharge (PR) (PDSIa). However, he acknowledged that this approach is not a particularly elegant manner of managing the problem, so he redefined PRO as three times the normal precipitation for a month (3P) minus the PR (PDSIb). He later mentioned that though this will continue to be an arbitrary approach, at least he recognized that $\mathrm{P}$ and AWC are not related concepts.

In this study, we used the PDSIb formulation for the estimation of PRO because the first PDSIa approach underestimates the number of droughts in the MRBD. For PDSI calculations, we used the version suggested for the Témez aggregated hydrological model (Pérez-Martín et al., 2015; Témez, 1977) for the Chone river basin (Carrizal river subbasin) and Portoviejo river (headwaters of the Portoviejo river and Chico river subbasin). The model was calibrated and validated obtaining a $4 \%$ bias and a Nash coefficient of 0.75 , rated as a good simulation according to (D. N. Moriasi et al., 2007). Table 2 shows the grading criteria for defining drought intensity generated from the PDSI (Wayne C. Palmer, 1965). 


\section{Results and discussion}

\subsection{Index evaluation and validation}

The drought analysis for the MRBD contemplated the period Oct./64 - Sep.t/12. SPI was calculated for 3, 6, 9, 12 and 24 months; in a distributed and aggregate form for MRBD (Fig. 4) and CZ, respectively (Fig. 5).

SPI-1, SPI-3 and SPI-6 showed normal conditions for Sep./82 in the NZ and CZ, and reflected drought events in the SZ (Fig. 4), whereas SPI-12 and SPI-24 showed droughts in the CZ and SZ, and normal conditions in the NZ. SPI-1 and SPI-3 showed droughts in the NZ and SZ in Sep.t/01, whereas SPI-12 and SPI-24 showed droughts only in the NZ. SPI-6 displayed normal conditions in the whole MRBD. These results occurred because the distributed calculations can capture the heterogeneity of the study area and the hydro-meteorological forcing, and therefore, can most appropriately represent the physical mechanisms that exist in reality (Mersel et al., 2013). 


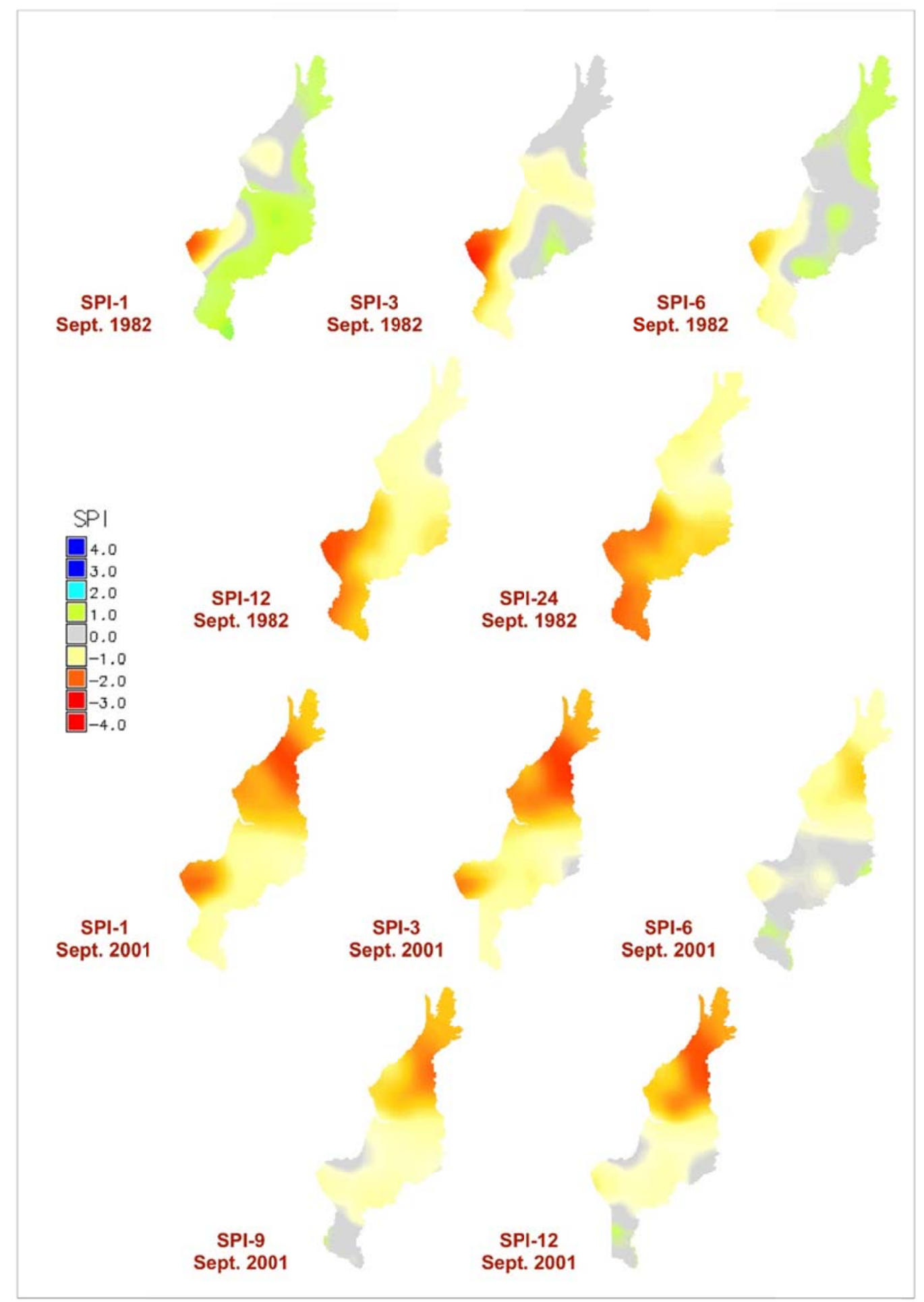

Figure 4.- SPI and MRBD distributed calculations for September 1982 and May 2001 at 1, 3, 6, 9, 12 and 24 months.

In the SPI-3, there is a greater frequency of historical droughts in the NZ. In the periods $1988 / 89$ - 1994/95, there is a decrease in droughts in the SZ, in relation to the 
other zones. The same occurs in the periods 2005/06-2010/11 in the NZ in relation to the SZ and CZ. However, the most severe droughts were observed in the SZ, perhaps due to the aridity levels of the area (Ríos and Josefina, 2016). The SPI-12 scale shows moderate droughts $(<-1.50)$ in the MRBD in the periods $1967 / 68,1978-1980$ and $1981 / 82$. In the NZ, the episode is manifested in the periods $1995-1997,2000 / 01$; in the CZ, in 1990-91; and in the SZ, in 1978-1982, with 1981/82 becoming a severe drought event $(<-2.00)$. The results showed a major presence of moderate droughts in the CZ.

In the SPI-3 and SPI-12, we identified extremely wet conditions $(>2.00)$ in the periods $1982 / 83$ and $1997 / 98$ due to the occurrence of the ENSO event, El Niño phase (Fig. 5).

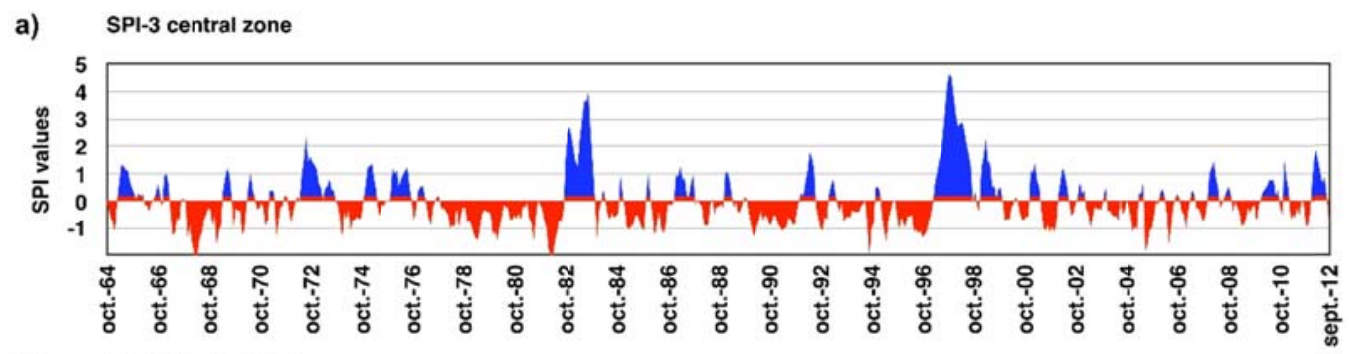

b) SPI-12 central zone

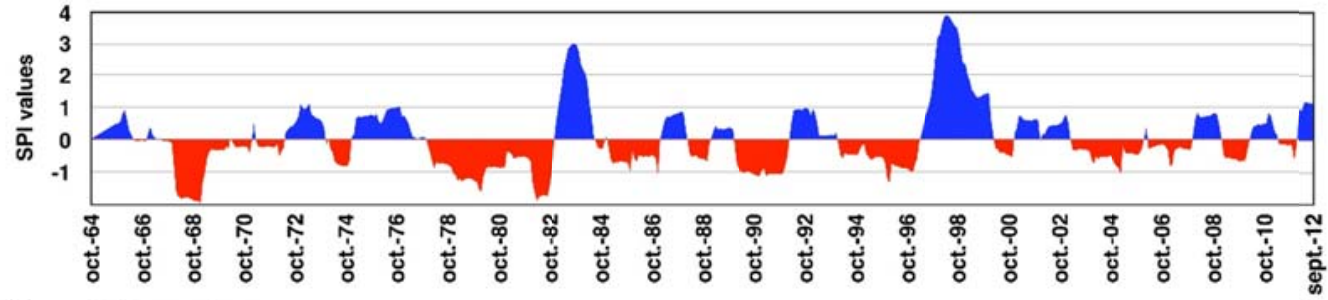

c)

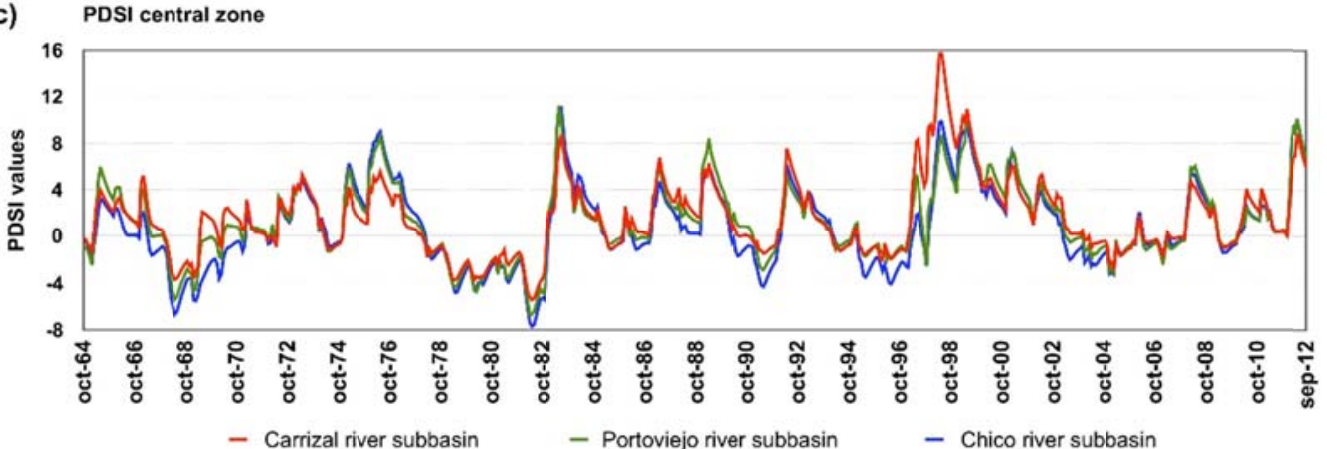

Figure 5.- Calculations of aggregate drought indices in the MRBD. a) SPI- 3 in the central zone. b) SPI-12 in the central zone. c) PDSI in the central zone in the Carrizal river subbasin, Chico river and headwaters of the Portoviejo river. 
For identifying droughts by means of the PDSI, we used the PDSIb formulation. The index was calculated from Oct./64 to Sep./12, at monthly scales, in three subbasins of the $\mathrm{CZ}$ in the MRBD (Fig. 5). In the Carrizal river subbasin, we identified extremely wet conditions $(>4)$ due to precipitation levels above the average in wet seasons, and temperatures below the mean level in the dry season. This resulted in excess soil moisture. Similar conditions were observed in the periods 1982/83 and 1997/98 following the occurrence of the ENSO event.

Likewise, there is evidence of two dry periods (Feb./68-Apr/69; Mar./77Nov./82) considered to be extreme $(<-4)$, three periods (Apr./90-Dec./90; Mar./95Jan./97; Dec./04-Nov./05) of moderate droughts $(-2.00$ to -2.99$)$; and six periods of decreased droughts $(-1.00 \mathrm{a}-1.99)$ and incipient droughts $(-0.50 \mathrm{a}-0.99)$. Similar events were observed in the Portoviejo river and Chico river subbasins.

Figure 6 shows the values from the PDSIa (Fig. 6a), and PDSIb (Fig. 6b). Using the first formulation, the extreme drought events were underestimated, whereas when using the second formulation, the events became visible. PDSI has been widely questioned because its resulting values cannot be compared among different climatological regions. To improve spatial comparability, we proposed a SelfCalibrating Palmer Drought Severity Index (sc_PDSI), which made it possible to most realistically represent climates in different locations (Wells et al., 2004). sc_PDSI produced better results than the original PDSI during the XX century in Europe and North America (van der Schrier et al., 2006a, 2006b, 2007).

The results obtained from the SPI-12 (Fig. 6c) were similar to those of the PDSI. Indices showed a very strong correlation (0.85) in the period of analysis. McKee et al., 1995 found that in most seasons in the United States, PDSI is highly correlated with SPI at 10 to 14 months, e.g., the PDSI in Fort Collins, Colorado, showed a correlation 
coefficient of approximately 0.9 with the SPI when it was close to 12 months. Based on the SPI-12, which was defined in the dry and wet condition categories (Table 2), the dry periods in the MRBD began in Feb./68. In the NZ, there was a moderate drought that became extreme in Feb./69 and ended in Jun./69. In the SZ, there was a severe drought that ended in Feb./69, followed by a moderate dry period until Apr./69. In the SZ, the drought was moderate and ended in Feb./69.

In Jan./79, there was another drought episode, which ended in Mar./80 in the NZ and $\mathrm{CZ}$, continuing until Jan./81 in the SZ. In Apr./81 a moderate drought started in the SZ, reaching extreme levels in Mar./82. The event ended in Nov./83. In the SZ, a moderate drought started in Apr./90 and ended in Jan./91. In Apr./91, the event reappeared and ended in Dec./91. In Dec./94, a moderate drought emerged in the NZ and ended in Apr./95, and another event started in Apr./00 and ended in Feb./01. The wet periods in the MRBD occurred in Mar./83-May/84 and Dec./97-Apr./99, the latter ended in Apr./99 in the NZ and CZ. In the SZ, the event continued until Jan./00, though it started to decrease from Apr./99. The last wet period occurred in the NZ and CZ from May/12-Sep./12.

In the MRBD, the dry periods generally start in April and last until November during a dry year. Similar conditions occur in the Esmeraldas River Basin District, located to the north of the MRBD, with dry and wet periods during the months that are considered to be dry (INAMHI, 2000). The distributions in the dry and wet periods were similar in the NZ, CZ and SZ in the MRBD (Fig. 4).

The period Feb./82-Dec./83 was the driest, whereas Dec./97-Apr./99 was the most humid due to the occurrence of ENSO, El Niño phase. The floods that were caused by this natural event caused serious financial and human losses (D'Ercole and Trujillo, 
2003). Neelin et al., (2000) agreed that during the years 1997 and 1998, the most severe

El Niño event was recorded.

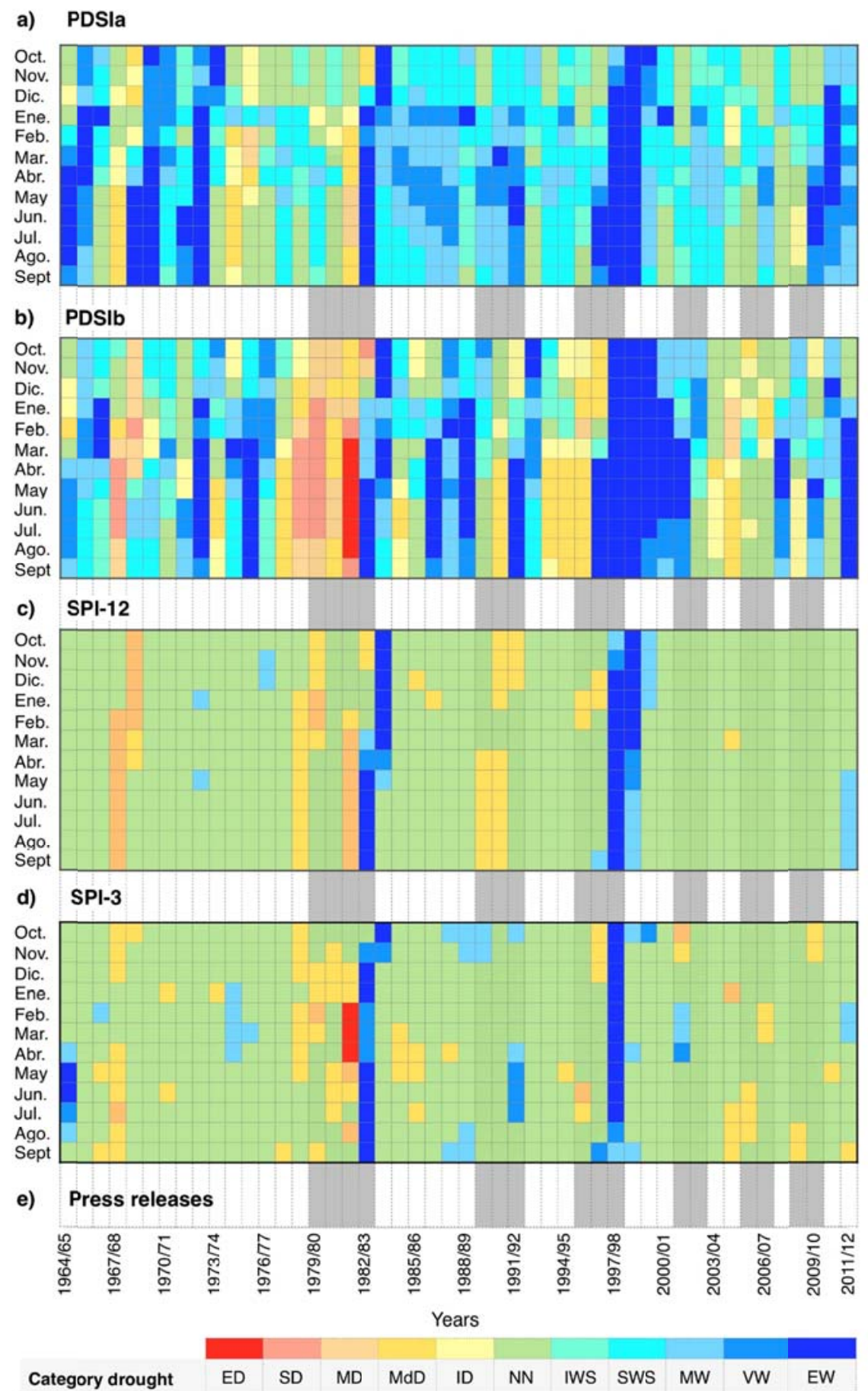

Figure 6.- Different drought index results in the central zone of the MRBD. a) PDSIa, where Potential Runoff is equal to the Available Water Capacity minus the Potential Recharge ( $\mathrm{PRO}=\mathrm{AWC}-\mathrm{PR})$; $\mathrm{b}$ ) PDSIb, where Potential Runoff is equal to three times Precipitation minus Potential Recharge (PRO=3PPR). c) SPI-12, used in the central zone of the MRBD. d) SP3-3, used in the central zone of the MRBD. e) Press releases addressing drought events. 
Based on the PDSI results, there were similarities in the dry and wet episodes between both indices in the period 1964/65-2000/01. Although, from the period 2003/04, the PDSI reflected drought events that were not visible in the SPI. The meteorological index was based only on precipitation records (McKee et al., 1995), and has not varied in the MRBD in the period 2000/01-2011/12 in relation to the average level in the period 1964/65 - 2000/01; whereas the agricultural index came from a soil water balance (Wayne C. Palmer, 1965) that considered the potential evapotranspiration (PET) as an input variable, which can vary according to temperature; thus the increase in the average temperature level from $0.1^{\circ} \mathrm{C}$ from the year 2001 in the MRBD was perhaps responsible for the difference of events between SPI and PDSI. Research from the Intergovernmental Panel on Climate Change (IPCC) claims that global average temperatures have increased $0.18^{\circ} \mathrm{C}$ every decade from 1951-2012 (Intergovernmental Panel on Climate Change, 2014)

Moreover, the drought categorization of each index must be considered. For example, the SPI index does not reflect droughts that are defined as mild, according to the PDSI categories (Table 2). The SPI does not categorize this type of droughts; therefore, it does not show it in the results. When the SPI shows moderate, severe and extreme droughts, so does the PDSI. However, when the PDSI reflects incipient and mild droughts, the SPI shows normal conditions. For example, in the year 2009, the PDSI indicated incipient drought in October and November, while the SPI indicated normal conditions. (Baringer et al., 2010) mention that, in November 2009, dry conditions were recorded in the coasts of Ecuador.

SPI-12 is considered to be a good agricultural indicator because it shows results that are similar to monthly PDSI, though, due to the variations in climate factors, PDSI is considered as the best agricultural indicator for the MRBD because it is based on a 
water balance model that uses both precipitation and temperature, as opposed to the SPI, which is based only on previous statistical precipitation records. Dai (2011) confirmed that PDSI is above other drought indices that are based on statistics, e.g. SPI, because the basic impact of global warming is considered through the Palmer water balance.

The results obtained from the SPI-12 and monthly PDSI were validated with the press releases addressing droughts that have been registered in the Disaster Inventory System. We determined the relationship between the events shown by the indices and the historical records from the year 1982. According to the records, agriculture was the mostly affected sector, with an impact on all the study zones. Records also make reference to the wet periods in the MRBD due to the occurrence of El Niño. In addition, we correlated the results from the SPI-12 and PDSI. Based on the historical press records (Table 1), the SPI-12 and monthly PDSI reflected the dry and wet periods shown in the NZ, CZ and SZ of the MRBD.

The SPI-3 is the indicator that coincides in its results in all the periods in which there was press registration; this is attributed to the number of registered drought events are short but of great intensity. The PDSI also coincides in large part with these events, but it does so by showing mild drought values that do not develop due to the rapid recovery of soil moisture. A joint use of these indexes on a small scale allows to obtain more reliable results in detection droughts. Figure 6 shows the coincidence between the results of PDSI, SPI-12 and SPI-3 indices values with the press releases shown in Table 1. 


\subsection{Frequency and duration of droughts}

Drought occurrence was analysed in Table 2, defining drought types in relation to SPI and PDSI values. With respect to this, the frequency distribution of the SPI-12 and monthly PDSI were divided into seven and eleven categories, respectively. The relationship between drought occurrence and each one of the categories of the SPI and PDSI and the total number of episodes counted for all the MRBD zones are represented as drought frequency.

The probability of the occurrence of moderate, severe and extreme droughts in the MRBD is shown for the period 1964/65 - 2011/12. According to the results from the SPI-12 to a month, moderate droughts had the highest frequency (11\% to $14 \%)$ and severe droughts had a frequency of $2 \%$ to $4 \%$ and extreme droughts, lesser than $2 \%$. The probability of drought occurrence for accumulated months to SPI-3, 12 is shown in Fig. 7. According to the PDSI values, the probability of occurrence of moderate droughts was $9.5 \%$, severe droughts, $5 \%$ and extreme droughts, $1 \%$ (Fig. 8). The duration of moderate, severe and extreme droughts can be up to nine months, one year and more than a year long, respectively. Incipient and mild droughts had a duration of nine months. In the MRBD, a severe drought has been observed every 13 years. Climate, Energy and Tenure Division, Deputy Directory-General Natural Resources, (2010) and D'Ercole and Trujillo, (2003) indicate that in the province of Manabí the

most common dry years occur due to precipitations that correspond to periods of drought return (10 and 25 years). For continuous periods, of two or more dry years, one of them has the risk of being extremely dry and every 25 years, two or more years have the risk of being dry. 

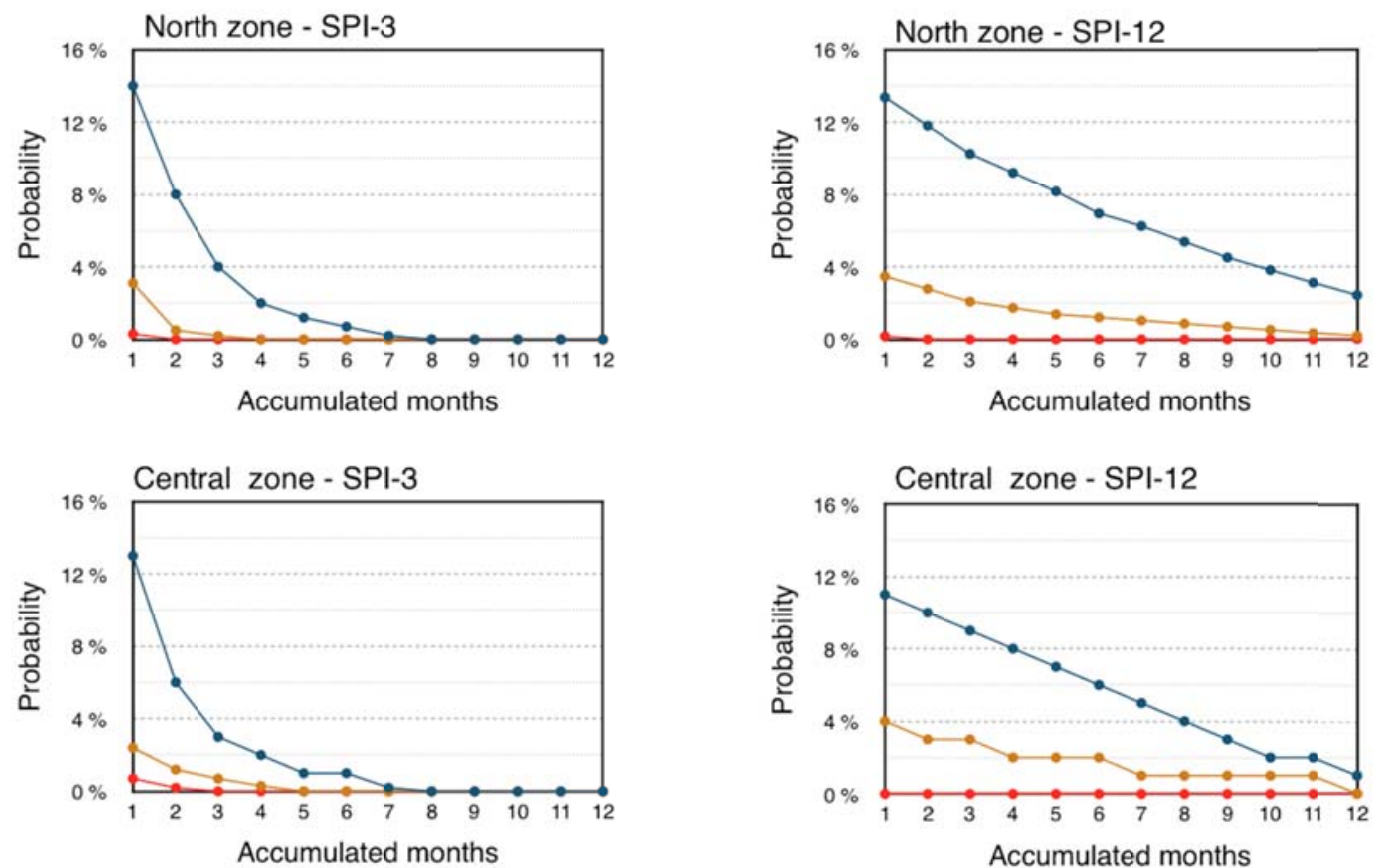

South zone - SPI-3
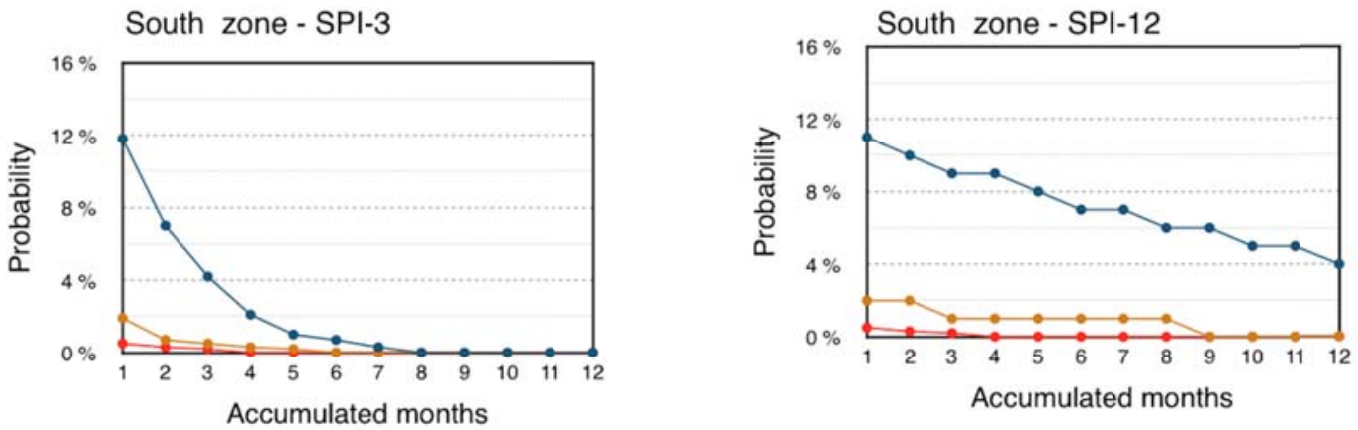

- Moderate drought - Severe drought - Extreme drought

Figure 7.- Probability of the occurrence of moderate, severe and extreme droughts, calculated from the indices. SPI-3 and SPI-12, north zone, central zone and south zone of the MRBD
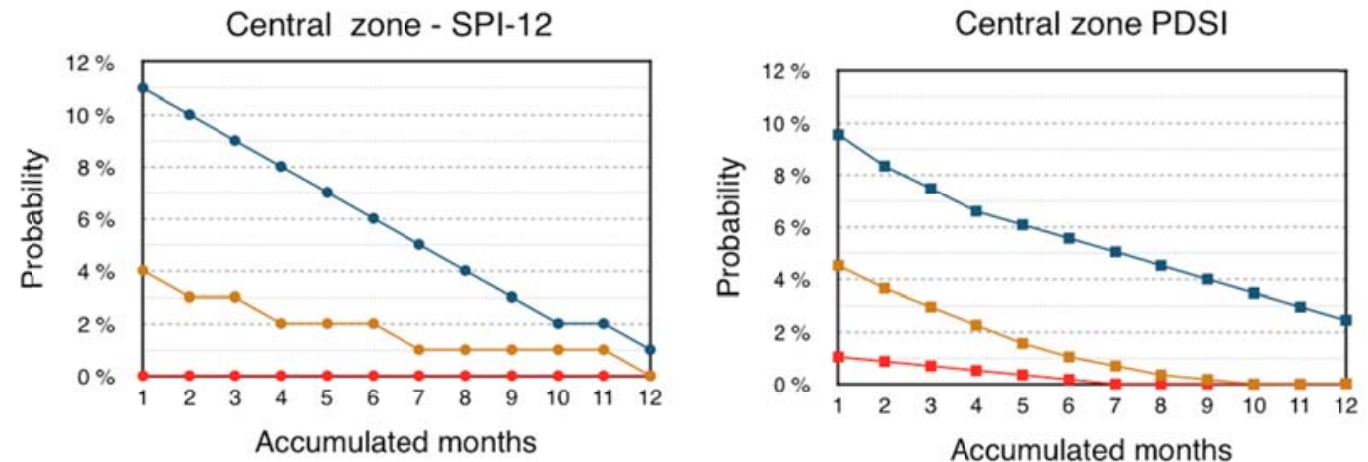

- Moderate drought - Severe drought - Extreme drought

Figure 8.- Probability of the occurrence of moderate, severe and extreme droughts, calculated from the indices. SPI-12 and PDSI in the central zone of the MRBD. 
The results obtained from the drought indices and validated through press releases allow concluded that, droughts in the Ecuadorian humid and subhumid tropical climates are of a short duration, can last between 3 and 9 months and are frequently incipient and mild. They appear in the dry season and end at the start of the wet season. In study area seasonal and annual droughts occur. After of the ENSO event, El Niño phase, there is no drought event for at least 3 years after the event. In the semiarid tropical climate, droughts can last for more than one year, becoming extreme.

Seasonal drought affects the agricultural sector due due the absence of rainfall in the wet season and annual drought affects the agricultural and livestock sector due to the water deficit which may lead to shortages in food production due to failure of crops; shortages of fodder and drinking water for cattle, even a decrease in the animal population. Seasonal drought occurs between the months of February and April. Annual drought is result of a seasonal drought which prolonged until the beginning next wet season. 


\subsection{Correlation between ENSO and droughts on the Ecuadorian coast}

The prediction of drought events related to ENSO are possible based only on observations, given the large temporal lag between the development of ENSO phenomena and the identification of drought conditions (Vicente-Serrano et al., 2011).

Pearson's $r$ correlation and cross-correlation with lag 1 to 12 months between climate indices SST, ONI and SOI, and drought indices SPI and PDSI were identified only from the year 1982 due to data availability issues. Table 3 presents a summary of the calculated Pearson's r correlation results. Results showed weak and very weak $(0.39$ to 0.13 ) correlations between SST Niño 3.4 region, SST Niño 4 region, ONI, and SOI, and the drought indices. However, there was a strong correlation between the SPI and SST Niño 1+2 region. These results are consistent with Coelho et al., (2002), who showed that, the closer a study area is to the $1+2$ Niño region, the higher the influence of the SST over the precipitation.

$\mathrm{CZ}$ is the zone with strongest correlation between SPI and SST Niño 1+2 region, followed by NZ and SZ. The SPI-3 and SST 1+2 region had a strong correlation in the NZ, CZ and SZ (Fig. 9a, 9d, 9g), whereas the SPI-6 showed strong correlations in the NZ and CZ (Fig. 9b, 9e) and moderate correlations in SZ (Fig. 9h). The SPI-12 showed moderate correlations in the three zones (Fig. 9c, 9f, 9i). Correlation between the SPI-3 and SST Niño 3 region was moderate in the NZ and CZ, but weak in the SZ. Correlation between SPI-6 and SST Niño 3 region was weak in the three zones, whereas the SPI-12 showed very weak correlations (Table 3).

The results showed a weak (0.38) correlation between PDSI and SST Niño 1+2 region. However; Figure 10 shows drought episodes (Fig. 10a) when there were long periods of negative anomalies in the SST Niño 1+2 region (Fig. 10b). Pearson's $r$ correlations between PDSI and remaining climate indices were very weak (Table 3). 
Research claims that El Niño, the warm phase of the ENSO cycle, frequently causes heavy rains along the equatorial and subtropical regions of Western South America (Vargas et al., 2006). In the coastal region of Ecuador, El Niño influences precipitations, significantly increasing their occurrence (Rossel, 1997), whereas studies carried out in the Amazon Region claim that La Niña, Niño $1+2$ region, causes a decrease in precipitations in the Paute region, however; this claim is preliminary (Heredia and Pombosa, 1999). In Entre Ríos, Argentine, La Niña is associated with severe drought occurrence (de Rojas and Alicia, 2000). In contrast, the dry periods in Australia are commonly associated with El Niño episodes (Chiew et al., 1998). In the southwestern region of Iran the El Niño phenomenon intensifies March - April floods compared with neutral conditions. The opposite is true in La Niña conditions (Saghafian et al., 2017). In Ecuador there will probably be warm conditions in ENSO associated with wetter than normal rainfall and cool conditions with drier scenarios (Cid-Serrano et al., 2015). (Vicente-Serrano et al., 2016) showed that El Niño $1+2$ index, in the Western plains are positive and dominantly significant whereas that in El Niño 3.4 index correlations are positive, but non-statistically significant. Therefore, El Niño $1+2$ index, is controlling drought variability in the Western plains. Drought episodes in the Western plains are better determined by cold SST conditions (La Niña) in the Eastern Pacific, this pattern is reinforced considering 3, 6 and 12 month SPEI. These results are consistent with those obtained in this research. 

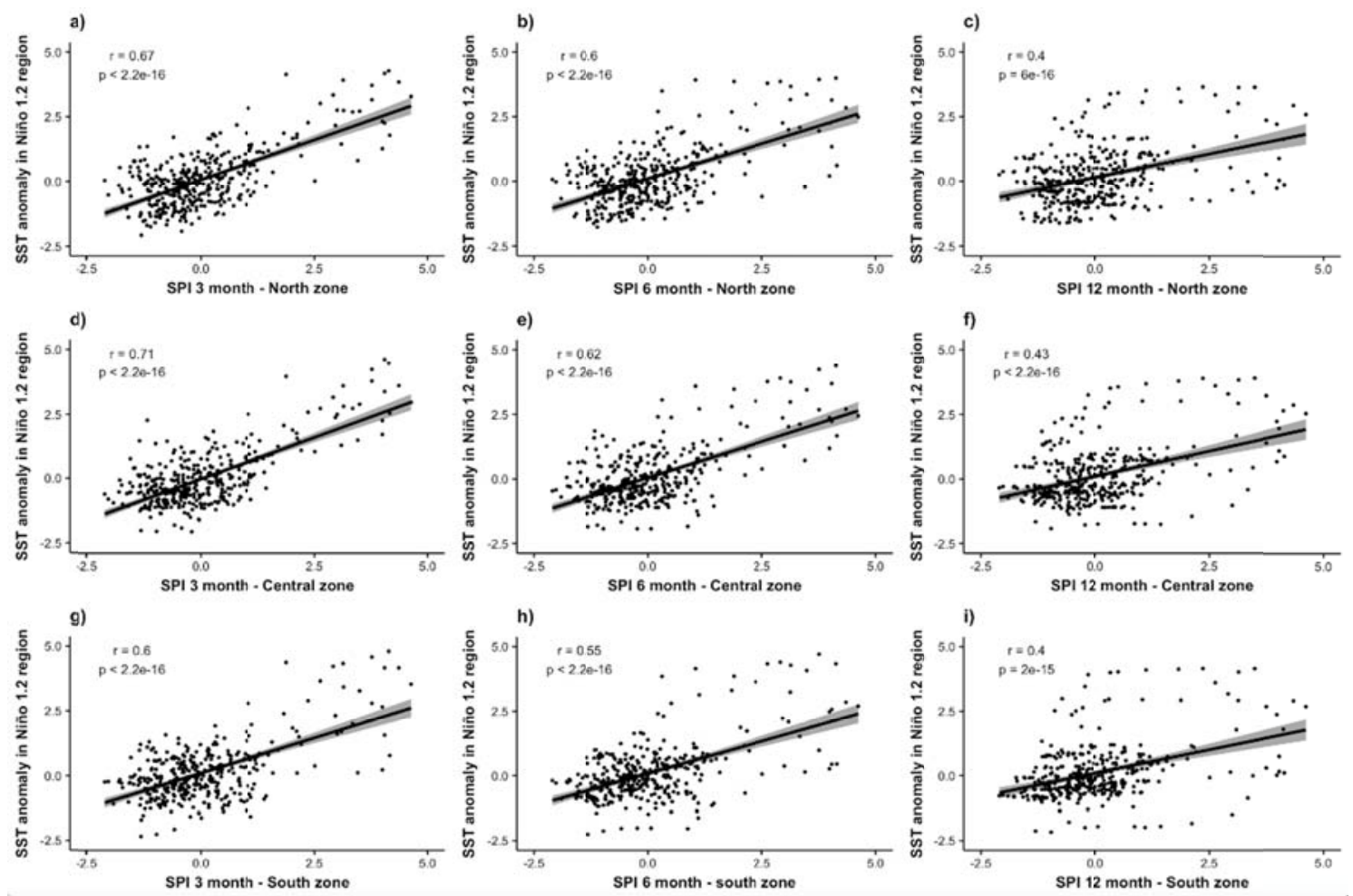

Figure 9.- Correlation between SPI-3, SPI-6, SPI-12 and SST anomalies of the 1+2 region in the north, central and south zones of the MRBD. Strength of the positive and negative correlation was evaluated using the Evans, (1996) guidelines: very weak: 0.00-0.019, weak: 0.20-0.39, moderate: 0.400.59 , strong: $0.60-0.79$, very strong: $0.80-1.0$.

Table 3 shows that the highest correlation coefficients were generally concentrated in the dry-subhumid megathermal and wet megathermal climates (NZ and CZ). Özger et al., (2009) mention that the PDSI and SST Niño 3 region and Niño 3.4 are highly correlated in the arid and continental regions of Texas, in comparison with the wet eastern regions. In the source region of the Yellow River, it is seen that ENSO events have an influence on summer precipitation, and that higher SST in equatorial Pacific areas corresponding to El Niño coincides with less summer precipitation (Yuan et al., 2016). 


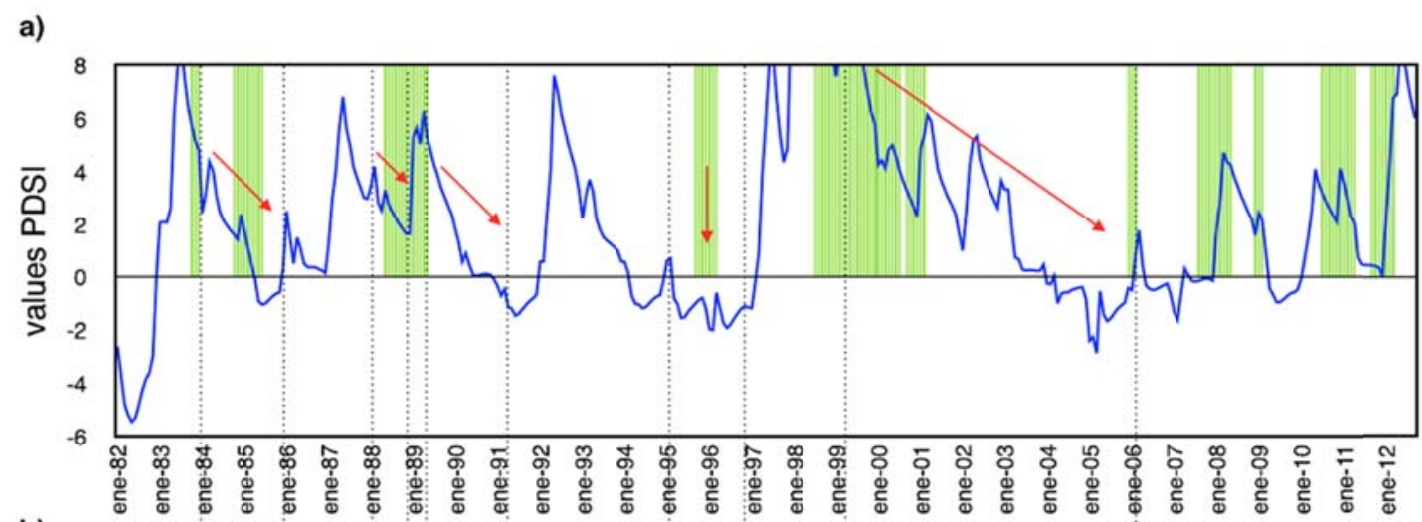

b)

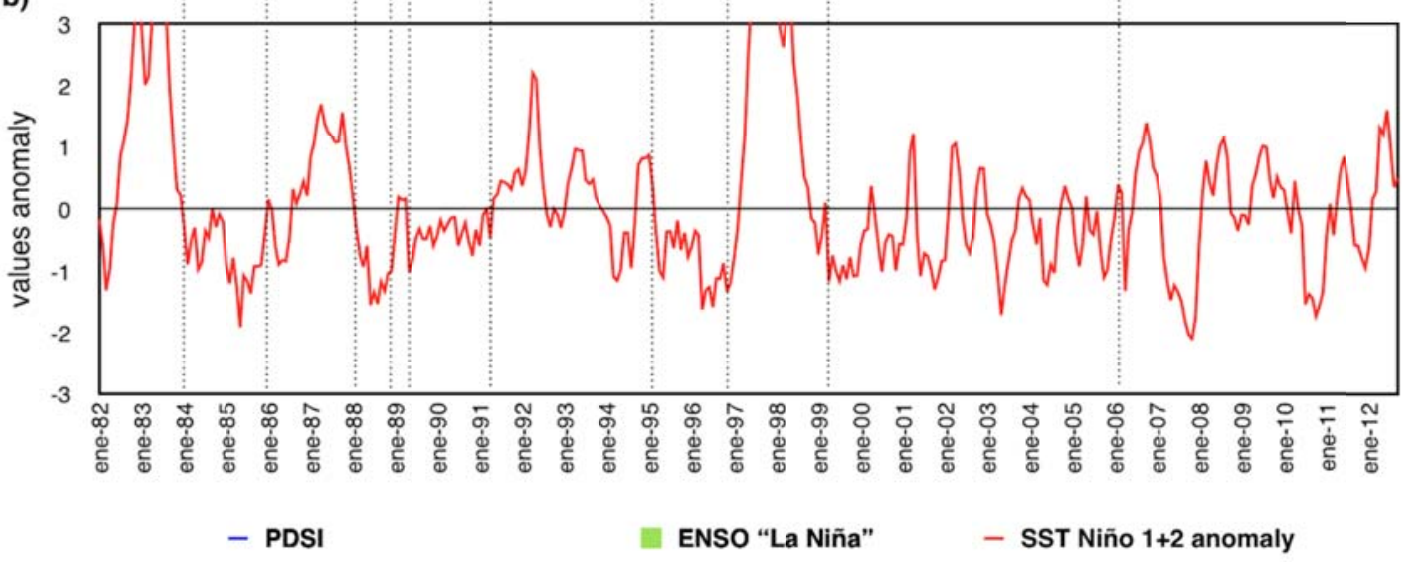

Figure 10.- a) PDSI values in the CZ of the MRBD and event ENSO "La Niña" phase, with an emphasis on index decrease in some periods. b) Anomalies of SST Niño 1+2 region, pinpointing long periods with negative values.

Table 4 presents a summary of the calculated Cross-correlation with lag 1 to 12 months results. Results indicated weak and very weak (0.39 to 0.14$)$ correlations between SST Niño 3.4 region, SST Niño 4 region, ONI, and SOI, andl drought indices SPI and PDSI. However, there was a strong $(0.62-0.72)$ correlation between SPI and SST Niño $1+2$ region. CZ is the zone with strongest correlation between SPI and SST Niño 1+2 region, followed by NZ and SZ. The SPI-1, 3, 6, 12 and SST 1+2 region had a strong correlation in the all zones, whereas the correlation with SST 3 region showed moderate $(0.40-0.59)$ correlation. The results showed a moderate $(0.44)$ correlation between PDSI and SST Niño 1+2 region, and correlations weak and very weak between PDSI and remaining climate indices. 
The cross-correlation shows the same pattern (lag $0,+1,+3,+7$ for SPI- 1 , SPI3, SPI-6 and SPI-12, respectively) in the three zones studied. The coefficients of crosscorrelation of the lag $+1,+3,+7$ between SST Niño $1+2$ and SPI, mean that the drought occurred 1 month, 3 months and seven months after the La Niña phenomenon began, respectively. The cross-correlation in lag 0 means that the events occurred simultaneously. We also identified the highest correlation between SPI-12 and SST Niño 3, 3.4 regions, ONI and SOI, with lag +9 and with lag +12 for SST Niño 4 region.

\begin{tabular}{lcccccccccc} 
& \multicolumn{3}{c}{ North zone } & \multicolumn{4}{c}{ Central zone } & \multicolumn{3}{c}{ South zone } \\
\cline { 2 - 10 } & $\begin{array}{c}\text { SPI 3 } \\
\text { month }\end{array}$ & $\begin{array}{c}\text { SPI 6 } \\
\text { month }\end{array}$ & $\begin{array}{c}\text { SPI 12 } \\
\text { month }\end{array}$ & $\begin{array}{c}\text { SPI 3 } \\
\text { month }\end{array}$ & $\begin{array}{c}\text { SPI 6 } \\
\text { month }\end{array}$ & $\begin{array}{c}\text { SPI 12 } \\
\text { month }\end{array}$ & $\begin{array}{c}\text { PDSI } \\
\text { monthly }\end{array}$ & $\begin{array}{c}\text { SPI 3 } \\
\text { month }\end{array}$ & $\begin{array}{c}\text { SPI 6 } \\
\text { month }\end{array}$ & $\begin{array}{c}\text { SPI 12 } \\
\text { month }\end{array}$ \\
\hline \hline SST 1+2 & 0.67 & 0.60 & 0.40 & 0.71 & 0.62 & 0.43 & 0.38 & 0.60 & 0.55 & 0.40 \\
SST 3 & 0.47 & 0.37 & 0.14 & 0.46 & 0.35 & 0.13 & 0.05 & 0.34 & 0.27 & 0.12 \\
SST 3.4 & 0.29 & 0.19 & -0.04 & 0.25 & 0.15 & -0.07 & 0.1 & 0.17 & 0.10 & -0.04 \\
SST 4 & 0.06 & -0.03 & -0.20 & -0.03 & -0.11 & -0.26 & 0.3 & -0.03 & -0.08 & -0.17 \\
ONI & 0.28 & 0.20 & 0.00 & 0.24 & 0.14 & 0.00 & 0.00 & 0.17 & 0.10 & 0.00 \\
SOI & 0.20 & 0.14 & 0.00 & 0.14 & 0.14 & 0.00 & 0.00 & 0.14 & 0.14 & 0.00 \\
\hline \hline
\end{tabular}

Table 3.- Pearson's r correlation results of the drought indices used for the north, central and south zones of the MRBD with climate indices ONI, SOI and SST.

\begin{tabular}{|c|c|c|c|c|c|c|c|c|c|c|c|c|c|}
\hline Zone & Index & & T 1+2 & & ST 3 & & T 3.4 & & ST 4 & & ONI & & SOl \\
\hline \multirow{4}{*}{ North } & SPI 1 & 0,62 & $\operatorname{lag} 0$ & 0,45 & $\operatorname{lag} 0$ & 0,36 & $\operatorname{lag}+4$ & 0,23 & $\operatorname{lag}+5$ & 0,35 & $\mathrm{lag}+1$ & $-0,30$ & $\operatorname{lag}+6$ \\
\hline & SPI 3 & 0,69 & $\operatorname{lag}+1$ & 0,50 & $\operatorname{lag}+1$ & 0,41 & $\operatorname{lag}+5$ & 0,26 & $\operatorname{lag}+7$ & 0,40 & $\operatorname{lag}+4$ & $-0,33$ & $\operatorname{lag}+6$ \\
\hline & SPI 6 & 0,67 & $\operatorname{lag}+3$ & 0,52 & $\operatorname{lag}+4$ & 0,42 & $\operatorname{lag}+6$ & 0,27 & $\operatorname{lag}+8$ & 0,42 & lag +6 & $-0,35$ & lag +7 \\
\hline & SPI 12 & 0,66 & $\mathrm{lag}+7$ & 0,56 & $\operatorname{lag}+9$ & 0,44 & lag +9 & 0,26 & $\mathrm{lag}+12$ & 0,44 & lag +9 & $-0,33$ & $\operatorname{lag}+9$ \\
\hline \multirow{5}{*}{ Central } & SPI 1 & 0,65 & $\operatorname{lag} 0$ & 0,45 & $\operatorname{lag} 0$ & 0,29 & $\operatorname{lag}+2$ & 0,14 & $\operatorname{lag}+5$ & 0,29 & $\operatorname{lag}+1$ & $-0,25$ & $\operatorname{lag}+2$ \\
\hline & SPI 3 & 0,72 & $\mathrm{lag}+1$ & 0,48 & $\operatorname{lag}+1$ & 0,31 & $\operatorname{lag}+3$ & 0,14 & $\operatorname{lag}+6$ & 0,31 & lag +3 & $-0,28$ & lag +4 \\
\hline & SPI 6 & 0,68 & $\operatorname{lag}+3$ & 0,47 & $\operatorname{lag}+4$ & 0,32 & $\operatorname{lag}+5$ & 0,15 & $\operatorname{lag}+8$ & 0,31 & $\operatorname{lag}+5$ & $-0,29$ & $\operatorname{lag}+7$ \\
\hline & SPI 12 & 0,64 & $\operatorname{lag}+7$ & 0,47 & $\operatorname{lag}+8$ & 0,33 & $\operatorname{lag}+9$ & 0,13 & lag +12 & 0,31 & lag +9 & $-0,26$ & $\operatorname{lag}+9$ \\
\hline & PDSI & 0,44 & $\operatorname{lag}+1$ & 0,27 & $\operatorname{lag}+7$ & 0,14 & $\operatorname{lag}+8$ & $-0,30$ & lag 0 & 0,13 & $\operatorname{lag}+1$ & $-0,10$ & $\operatorname{lag} 0$ \\
\hline \multirow{4}{*}{ South } & SPI 1 & 0,56 & $\operatorname{lag} 0$ & 0,42 & $\operatorname{lag}+4$ & 0,35 & $\operatorname{lag}+5$ & 0,21 & $\operatorname{lag}+7$ & 0,34 & $\operatorname{lag}+5$ & $-0,35$ & $\operatorname{lag}+6$ \\
\hline & SPI 3 & 0,62 & $\operatorname{lag}+1$ & 0,45 & $\operatorname{lag}+5$ & 0,38 & $\operatorname{lag}+6$ & 0,22 & $\operatorname{lag}+8$ & 0,37 & $\operatorname{lag}+6$ & $-0,36$ & lag +6 \\
\hline & SPI 6 & 0,63 & $\operatorname{lag}+3$ & 0,48 & $\operatorname{lag}+6$ & 0,39 & $\operatorname{lag}+7$ & 0,21 & $\operatorname{lag}+9$ & 0,38 & $\operatorname{lag}+7$ & $-0,37$ & $\operatorname{lag}+7$ \\
\hline & SPI 12 & 0,66 & $\mathrm{lag}+7$ & 0,52 & $\operatorname{lag}+9$ & 0,39 & lag +9 & 0,19 & $\operatorname{lag}+11$ & 0,38 & lag +9 & $-0,34$ & $\operatorname{lag}+9$ \\
\hline
\end{tabular}

Table 4.- Cross-correlation results of the drought indices used for the north, central and south zones of the MRBD with climate indices ONI, SOI and SST. 
The cross-correlation showed strong correlations between SPI and SST Niño 1+2 region, moderate correlations between SPI and SST Niño 3, 3.4 regions, ONI and SOI, and weak correlations between SPI and SST Niño 4 region. These results allow to predict short and long-term drought events using the respective lag, and indicate precipitation in study area varies according to sea temperature. 


\subsection{Early Drought Detection}

Early drought detection help in achieving a greater level of drought preparedness (D. A. Wilhite et al., 2000), allow to predict the occurrence and impact of drought and to elicit a timely response.

For early drought detection we have combined drought indices with ENSO. We use SPI and PDSI with SST Niño regions. To detect drought early, it is necessary the following observations must made before start of wet season: (1) previous anomalies of SST Niño $1+2,3$ and 3.4 regions, and their future trend, to identify if there will be anomalous conditions in the rainfall of wet season next and (2) the behaviour of SPI-3, SPI-12 and PDSI. In Figure 11 is show how a seasonal drought can be detected early, taking as an example extreme drought of 1982, where, in December month that marks the beginning of wet season, anomalies of SST are analysed in Niño $1+2$ region, with lag -7 (May-November) and in Niño 3 and 3.4 regions with lag -9 (March-December). In addition, behaviour of PDSI in previous months should be observed, if value PDSI is close to zero, the probability of drought occurrence increases.

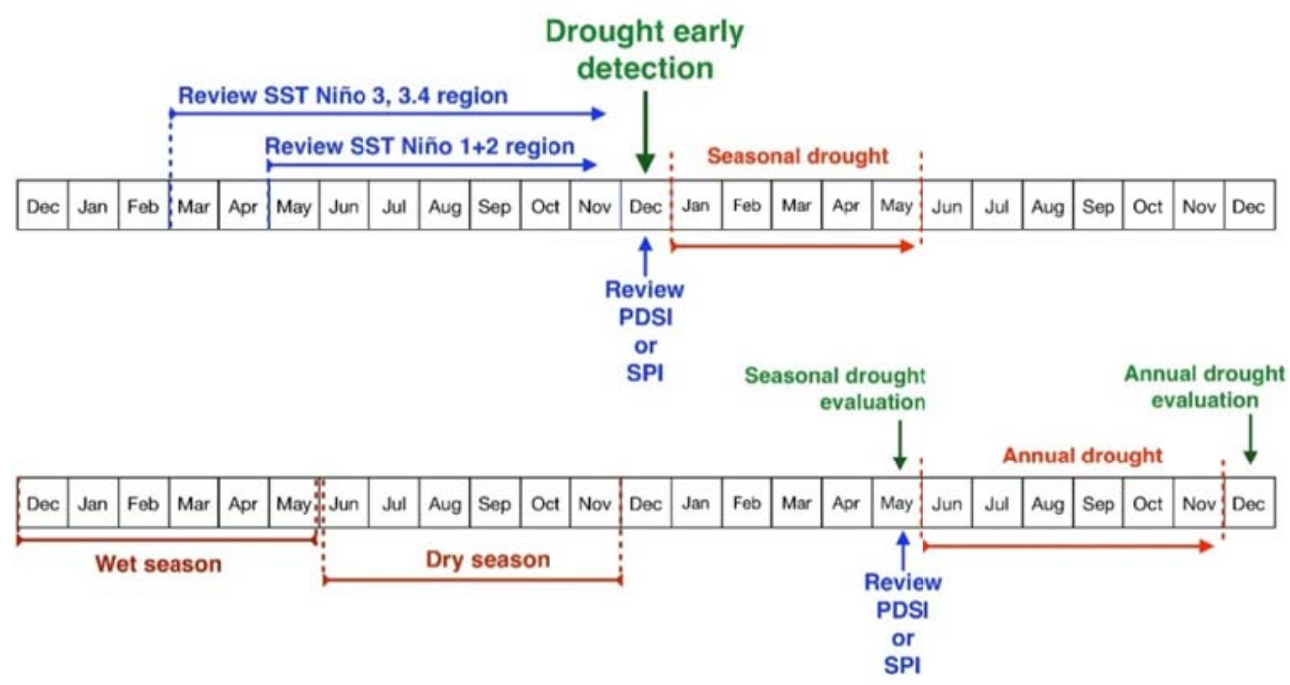

Figure 11.- Early drought detection system applied in December and May (data used in blue colour). 
To detect an annual drought, evolution of wet season should be evaluated, knowing that, if normal rainfall was recorded in wet season the occurrence of an annual drought is unlikely. However, when registering values below the average, the probability of occurrence of drought is high. In Figure 12, is exemplified application of the procedure of early drought detection. To issue early drought detection the criteria established in Table 5 should be considered, these are based on analysis of drought indices values applied in study area and SST anomaly values, following established procedure in figure 11 .

\begin{tabular}{cccccc}
\hline $\begin{array}{c}\text { Months of } \\
\text { evaluation }\end{array}$ & $\begin{array}{c}\text { Drought index } \\
\text { used }\end{array}$ & $\begin{array}{c}\text { Drought } \\
\text { Index range }\end{array}$ & $\begin{array}{c}\text { SST 1+2 } \\
\text { range }\end{array}$ & $\begin{array}{c}\text { Drought } \\
\text { Probability }\end{array}$ & Type of drought \\
\hline \hline December / May & PDSI & $>0.5$ & $<-0.5$ & High & Seasonal / Annual \\
December / May & SPI-12 & $>1$ & $<-0.5$ & High & Seasonal / Annual \\
December / May & PDSI & $>0.5$ & $>-0.5-<0.5$ & Medium & Seasonal / Annual \\
December / May & SPI-12 & $>1$ & $>-0.5-<0.5$ & Medium & Seasonal / Annual \\
December / May & PDSI & $>0.5$ & $>0.5$ & Low & Seasonal / Annual \\
December / May & SPI-12 & $>1$ & $>0.5$ & Low & Seasonal / Annual \\
December / May & PDSI & $1-0$ & $<-0.5$ & High & Seasonal / Annual \\
December / May & SPI-12 & $0->-0.5$ & $<-0.5$ & High & Seasonal / Annual \\
December / May & PDSI & $1-0$ & $>-0.5-<0.5$ & Medium & Seasonal / Annual \\
December / May & SPI-12 & $0->-0.5$ & $>-0.5-<0.5$ & Medium & Seasonal / Annual \\
December / May & PDSI & $1-0$ & $>0.5$ & Low & Seasonal / Annual \\
December / May & SPI-12 & $0->-0.5$ & $>0.5$ & Low & Seasonal / Annual \\
December / May & PDSI & $<-0.5$ & $<-0.5$ & High & Seasonal / Annual \\
December / May & SPI-12 & $<-1$ & $<-0.5$ & High & Seasonal / Annual \\
December / May & PDSI & $<-0.5$ & $>-0.5-<0.5$ & Medium & Seasonal / Annual \\
December / May & SPI-12 & $<-1$ & $>-0.5-<0.5$ & Medium & Seasonal / Annual \\
December / May & PDSI & $<-0.5$ & $>0.5$ & Low & Seasonal / Annual \\
December / May & SPI-12 & $<-1$ & $>0.5$ & Low & Seasonal / Annual \\
\hline Tab $5 .-$ Cit I
\end{tabular}

Table 5.- Criteria defined to establish the probability of future drought appearance. 


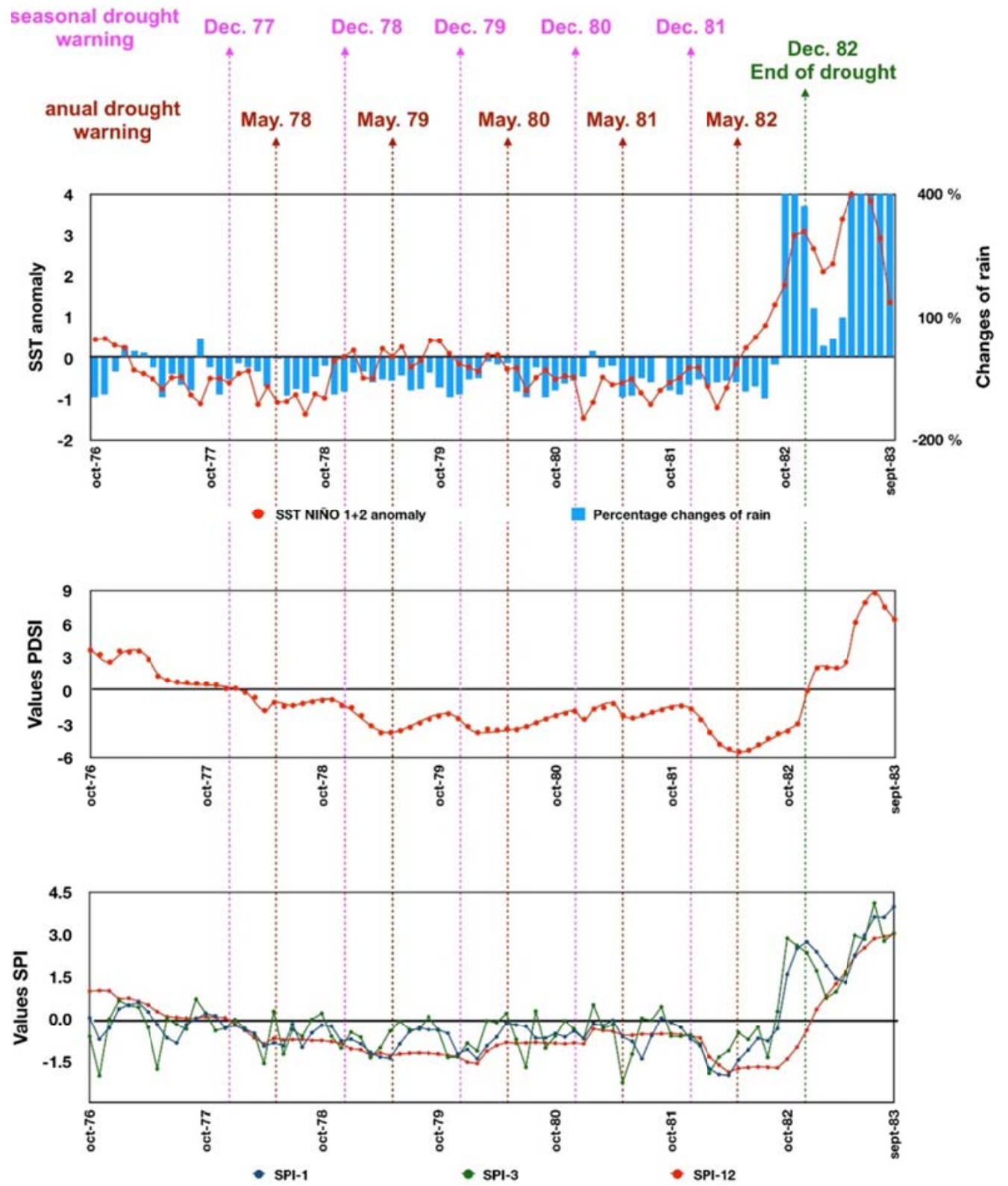

Figure 12.- Application of the procedure of early drought detection in the extreme drought of 1982 in the MRBD.

As limitations, the available hydrological data in the entire Ecuador are scarce, which can make less reliable the application of the proposed method in other watersheds with severe lack of data. In relation, with future developments, the automatic link between the proposed system and the implementation of droughts measures can contribute to reduce delays in the decision making process and, then, mitigate impacts of droughts. 


\section{Conclusions}

The manuscript presents a drought forecasting system, based on ENSO and Drought Indicators in the tropical climate of Manabí River Basin District. The main ENSO climate indices (ONI, SOI, and SST) for this area are used and two drought indices (SPI - PDSI) are developed of this river basin.

The PDSI calculation is based on the results obtained from a calibrated water balance model for this river basin, instead the original water balance model defined by Palmer. The results about drought occurrence have been validated with the real press releases; also, droughts analysis shows that there are two types of droughts in this area, seasonal and annual droughts.

The most dominant relationship, in all cases, between ENSO and drought indices was with the SST Niño $1+2$ region climate index. The Pearson's r Correlation was 0.71 and the cross-correlation shows that the SST Niño 1+2 region strongly influences in occurrence of drought with SPI-1 (0.61), SPI-3 (0.67), SPI-6 (0.66), SPI$12(0.66)$ in lag $0,+1,+3,+7$ respectively. Although it was also observed, highest correlation between SST Niño 3, 3.4 regions, ONI and SOI, with SPI-12 in lag $+9(0.52$, $0.39,0.38$, and -0.31 , respectively) and for SST Niño 4 region with SPI-12 in lag +12 $(0.20)$.

The early drought detection system is based on SST 1+2 (lag -7), 3 (lag -9) and 3.4 (lag -9) anomalies and both drought indices. The proposed system must be applied in December, for detect the season drought, and in May, for detect the annual drought. This system could improve the water management under drought conditions.

\section{Acknowledgment}

The authors thank the Secretariat of Higher Education, Science, Technology and Innovation of Ecuador (Secretaría de Educación Superior, Ciencia, Tecnología e 
Innovación, SENESCYT) for funding this research in the scholarship program: “CONVOCATORIA ABIERTA 2012, 2ª FASE” (contract 323-2012).

We would also like to express our gratitude to the National Institute of Meteorology and Hydrology (Instituto Nacional de Meteorología e Hidrología INAMHI) and Geographic Military Institute (Instituto Geográfico Militar - IGM) of Ecuador for providing data to develop this study. 


\section{References}

Baringer, M.O., Arndt, D.S., Johnson, M.R., 2010. State of the climate in 2009. Bull. Am. Meteorol. Soc. 91, S1-+. https://doi.org/10.1175/BAMS-91-7StateoftheClimate

Barlow, M., Nigam, S., Berbery, E.H., 2001. ENSO, Pacific decadal variability, and US summertime precipitation, drought, and stream flow. J. Clim. 14, 2105-2128. https://doi.org/10.1175/1520-0442(2001)014<2105:EPDVAU>2.0.CO;2

Barua, S., Ng, A.W.M., Perera, B.J.C., 2015. Drought Assessment and Forecasting: A Case Study on the Yarra River Catchment in Victoria, Australia. Australas. J. Water Resour. 15, 95-108. https://doi.org/10.7158/13241583.2012.11465393

Bell, G.D., Halpert, M.S., Kousky, V.E., Gelman, M.E., Ropelewski, C.F., Douglas, A.V., Schnell, R.C., 1999. Climate Assessment for 1998. Bull. Am. Meteorol. Soc. $\quad 80, \quad 1040-1040 . \quad$ https://doi.org/10.1175/15200477(1999) $080<1040: \mathrm{CAF}>2.0 . \mathrm{CO} ; 2$

Bhalme, H.N., Mooley, D.A., 1980. Large-Scale Droughts/Floods and Monsoon Circulation. Mon. Weather Rev. 108, 1197-1211. https://doi.org/10.1175/15200493(1980)108<1197:LSDAMC>2.0.CO;2

Chiew, F.H.S., Piechota, T.C., Dracup, J.A., McMahon, T.A., 1998. El Nino/Southern Oscillation and Australian rainfall, streamflow and drought: Links and potential for forecasting. J. Hydrol. 204, 138-149. https://doi.org/10.1016/S00221694(97)00121-2

CHJ, 2007. Plan especial de Alerta y eventual sequia en la Confederacion Hidrografica del Jucar. Minist. Medioambiente Valencia.

Cid-Serrano, L., Ramírez, S.M., Alfaro, E.J., Enfield, D.B., 2015. Analysis of the latin american west coast rainfall predictability using an enso index. Atmósfera 28, 191-203. https://doi.org/10.20937/ATM.2015.28.03.04

Climate, Energy and Tenure Division, Deputy Directory-General Natural Resources, 2010. Sistematización de Prácticas para el aprovechamiento de recursos naturales en la cuenca del Chone en Ecuador. FAO, Rome.

Coelho, C. a. S., Uvo, C.B., Ambrizzi, T., 2002. Exploring the impacts of the tropical Pacific SST on the precipitation patterns over South America during ENSO periods. Theor. Appl. Climatol. 71, 185-197. https://doi.org/10.1007/s007040200004

D. N. Moriasi, J. G. Arnold, M. W. Van Liew, R. L. Bingner, R. D. Harmel, T. L. Veith, 2007. Model Evaluation Guidelines for Systematic Quantification of Accuracy in Watershed Simulations. Trans. ASABE 50, 885-900. https://doi.org/10.13031/2013.23153

Dai, A., 2011. Characteristics and trends in various forms of the Palmer Drought Severity Index during 1900-2008. J. Geophys. Res.-Atmospheres 116, D12115. https://doi.org/10.1029/2010jd015541

De Martino, G., De Paola, F., Fontana, N., Marini, G., Ranucci, A., 2012. Experimental assessment of level pool routing in preliminary design of floodplain storage. Sci. Total Environ. 416, 142-147. https://doi.org/10.1016/j.scitotenv.2011.11.032 
De Paola, F., Galdiero, E., Giugni, M., Pugliese, F., 2015. Sustainable Development of Storm-water Systems in African Cities Considering Climate Change. Procedia Eng., Computing and Control for the Water Industry (CCWI2015) Sharing the best practice in water management 119, 1181-1191. https://doi.org/10.1016/j.proeng.2015.08.970

de Rojas, C., Alicia, E., 2000. The climatic impact of La Niña-related droughts in Entre Rios (Argentina). Drought Netw. News 1994-2001 15.

D'Ercole, R., Trujillo, M., 2003. Hazards, vulnerability, capabilities and risk in Ecuador.

Díaz, G., Manuel, J., 2014. Uso correcto de la correlación cruzada en Climatología: el caso de la presión atmosférica entre Taití y Darwin. Terra Nueva Etapa 30, 79102.

Edwards, D.C., McKee, T.B., 1997. Characteristics of 20th century drought in the United States at multiple time scales (Report). Colorado State University. Libraries.

Engle, N.L., 2013. The role of drought preparedness in building and mobilizing adaptive capacity in states and their community water systems. Clim. Change 118, 291-306. https://doi.org/10.1007/s10584-012-0657-4

Estrela, T., Vargas, E., 2012. Drought Management Plans in the European Union. The Case of Spain. Water Resour. Manag. 26, 1537-1553. https://doi.org/10.1007/s11269-011-9971-2

Evans, J.D., 1996. Straightforward statistics for the behavioral sciences. Brooks/Cole Pub. Co., Pacific Grove.

FAO, 2013. Paving the way for national drought policies.

Gibbs, W.J., Maher, J.V., 1967. Rainfall deciles as drought indicators. Melbourne: Bureau of Meteorology.

Gómez-Martínez, G., Pérez-Martín, M.A., Estrela-Monreal, T., del-Amo, P., 2018. North Atlantic Oscillation as a Cause of the Hydrological Changes in the Mediterranean (Júcar River, Spain). Water Resour. Manag. 1-18. https://doi.org/10.1007/s11269-018-1954-0

Gommes, R., Petrassi, F., 1996. Rainfall variability and drought in sub-Saharan Africa. Adapt. FAO Agrometeorol. Ser. Work. Pap. 9.

Gutiérrez, A.P.A., Engle, N.L., De Nys, E., Molejón, C., Martins, E.S., 2014. Drought preparedness in Brazil. Weather Clim. Extrem., High Level Meeting on National Drought Policy 3, 95-106. https://doi.org/10.1016/j.wace.2013.12.001

Haile, M., 2005. Weather patterns, food security and humanitarian response in subSaharan Africa. Philos. Trans. R. Soc. B Biol. Sci. 360, 2169-2182. https://doi.org/10.1098/rstb.2005.1746

Hastenrath, S., 1985. Climate and circulation of the tropics. Springer Netherlands, Dordrecht. https://doi.org/10.1007/978-94-009-5388-8

Hayes, M., 1996. Drought indexes. Natl. Drought Mitig. Cent. Univ. Nebraska-Lincoln 7. 
Heredia, E., Pombosa, R., 1999. Influencia del ENSO sobre los caudales mensuales de las grandes cuencas hidrográficas del Ecuador. Hydrol. Geochem. Process. Large Scale River Basins.

Hollinger, S.E., Isard, S.A., Welford, M.R., 1993. A new soil moisture drought index for predicting crop yields, in: Preprints, Eighth Conference on Applied Climatology. pp. 187-190.

INAMHI, 2000. Análisis del impacto del cambio climático en los recursos hídricos en el Ecuador.

Intergovernmental Panel on Climate Change, 2014. Observations: Atmosphere and Surface, in: Climate Change 2013 - The Physical Science Basis: Working Group I Contribution to the Fifth Assessment Report of the Intergovernmental Panel on Climate Change. Cambridge University Press, pp. 159-254. https://doi.org/10.1017/CBO9781107415324.008

Keetch, J.J., Byram, G.M., 1968. A Drought Index for Forest Fire Control. Res Pap SE38 Asheville NC US Dep. Agric. For. Serv. Southeast. For. Exp. Stn. 35 P 038.

Kundzewicz, Z.W., Mata, L.J., Arnell, N.W., Döll, P., Kabat, P., Jiménez, B., Miller, K.A., Oki, T., Sen, Z., Shiklomanov, I.A., 2007. Freshwater resources and their management, in: Climate Change 2007: Impacts, Adaptation and Vulnerability. Contribution of Working Group II to the Fourth Assessment Report of the Intergovernmental Panel on Climate Change. Cambridge University Press, Cambridge, United Kingdom and New York, NY, USA.

Latrubesse, E.M., Stevaux, J.C., Sinha, R., 2005. Tropical rivers. Geomorphology 70, 187-206. https://doi.org/10.1016/j.geomorph.2005.02.005

Lee, J.H., Julien, P.Y., 2016. Teleconnections of the ENSO and South Korean precipitation patterns. J. Hydrol. 534, 237-250. https://doi.org/10.1016/j.jhydrol.2016.01.011

Liu, W.T., Kogan, F.N., 1996. Monitoring regional drought using the Vegetation Condition Index. Int. J. Remote Sens. 17, 2761-2782. https://doi.org/10.1080/01431169608949106

McKee, T.B., Doesken, N.J., Kleist, J., 1995. Drought monitoring with multiple time scales, in: Proceedings of the 9th Conference on Applied Climatology. American Meteorological Society Dallas, Boston, MA, pp. 233-236.

McKee, T.B., Doesken, N.J., Kleist, J., 1993. The relationship of drought frequency and duration to time scales, in: Proceedings of the 8th Conference on Applied Climatology. American Meteorological Society Boston, MA, pp. 179-183.

Mersel, M.K., Smith, L.C., Andreadis, K.M., Durand, M.T., 2013. Estimation of river depth from remotely sensed hydraulic relationships. Water Resour. Res. 49, 3165-3179. https://doi.org/10.1002/wrcr.20176

Meyer, J.L., Pulliam, W.M., 1992. Modification of terrestrial—aquatic interactions by a changing climate, in: Global Climate Change and Freshwater Ecosystems. Springer, pp. 177-191.

Meyer, S.J., Hubbard, K.G., 1995. Extending the crop-specific drought index to soybean, in: Preprints, Ninth Conference on Applied Climatology. pp. 233-236. 
Meza, F.J., 2013. Recent trends and ENSO influence on droughts in Northern Chile: An application of the Standardized Precipitation Evapotranspiration Index. Weather Clim. Extrem. 1, 51-58. https://doi.org/10.1016/j.wace.2013.07.002

Mishra, A.K., Singh, V.P., 2010. A review of drought concepts. J. Hydrol. 391, 202216. https://doi.org/10.1016/j.jhydrol.2010.07.012

Neelin, J.D., Jin, F.-F., Syu, H.-H., 2000. Variations in ENSO Phase Locking. J. Clim. 13, 2570-2590. https://doi.org/10.1175/15200442(2000)013<2570:VIEPL $>2.0 . \mathrm{CO} ; 2$

Ortega-Gómez, T., Pérez-Martín, M.A., Estrela, T., 2018. Improvement of the drought indicators system in the Júcar River Basin, Spain. Sci. Total Environ. 610-611, 276-290. https://doi.org/10.1016/j.scitotenv.2017.07.250

Özger, M., Mishra, A.K., Singh, V.P., 2009. Low frequency drought variability associated with climate indices. J. Hydrol. 364, 152-162. https://doi.org/10.1016/j.jhydrol.2008.10.018

Palmer, W.C., 1968. Keeping Track of Crop Moisture Conditions, Nationwide: The New Crop Moisture Index. Weatherwise 21, 156-161. https://doi.org/10.1080/00431672.1968.9932814

Palmer, Wayne C., 1965. Meteorological drought. US Department of Commerce, Weather Bureau Washington, DC.

Palmer, W. C., 1965. Meteorologic drought, Research Paper No 45. US Weather Bur. Wash.

Paola, F. de, Ranucci, A., Feo, A., 2013. Antecedent Moisture Condition (scs) Frequency Assessment: A Case Study in Southern Italy. Irrig. Drain. 62, 61-71. https://doi.org/10.1002/ird.1801

Pedro-Monzonís, M., Solera, A., Ferrer, J., Estrela, T., Paredes-Arquiola, J., 2015. A review of water scarcity and drought indexes in water resources planning and $\begin{array}{llll}\text { management. } & \text { J. Hydrol. } & \text { 482-493. }\end{array}$ https://doi.org/10.1016/j.jhydrol.2015.05.003

Penman, H.L., 1948. Natural evaporation from open water, bare soil and grass, in: Proceedings of the Royal Society of London A: Mathematical, Physical and Engineering Sciences. The Royal Society, pp. 120-145.

Pérez-Martín, M.A., Batán, A., del-Amo, P., Moll, S., 2015. Climate change impact on water resources and droughts of AR5 scenarios in the Jucar River, Spain. Presented at the Drought: Research and Science-Policy Interfacing - Proceedings of the International Conference on Drought: Research and Science-Policy Interfacing, pp. 189-194.

Pérez-Martín, M.A., Estrela, T., Andreu, J., Ferrer, J., 2014. Modeling Water Resources and River-Aquifer Interaction in the Júcar River Basin, Spain. Water Resour. Manag. 28, 4337-4358. https://doi.org/10.1007/s11269-014-0755-3

Pielke, R.A., Landsea, C.N., 1999. La Niña, El Niño and Atlantic Hurricane Damages in the United States. Bull. Am. Meteorol. Soc. 80, 2027-2033. https://doi.org/10.1175/1520-0477(1999)080<2027:LNAENO>2.0.CO;2 
Pourrut, P., 1983. Los Climas del Ecuador, Documentos de investigacion (Centro Ecuatoriano de Investigacion Geografica); no. 4. Centro Ecuatoriano de Investigacion Geografica, [Quito].

Ríos, C., Josefina, S., 2016. Métodos de ajuste y homogenización de datos climáticos para determinar índice de humedad de Lang en la provincia de Manabí, Ecuador.

Rossel, F., 1997. Influencia de El Niño sobre los regimenes hidro - pluviométricos del Ecuador [WWW Document]. URL http://www.crid.or.cr/digitalizacion/pdf/spa/doc10166/doc10166.htm (accessed 1.12.18).

Saghafian, B., Haghnegahdar, A., Dehghani, M., 2017. Effect of ENSO on annual maximum floods and volume over threshold in the southwestern region of Iran. Hydrol. Sci. J. 62, 1039-1049. https://doi.org/10.1080/02626667.2017.1296229

Shafer, B.A., Dezman, L.E., 1982. Development of a Surface Water Supply Index (SWSI) to assess the severity of drought conditions in snowpack runoff areas, in: Proceedings of the Western Snow Conference. Colorado State University Fort Collins CO, pp. 164-175.

Shiferaw, B., Tesfaye, K., Kassie, M., Abate, T., Prasanna, B.M., Menkir, A., 2014. Managing vulnerability to drought and enhancing livelihood resilience in subSaharan Africa: Technological, institutional and policy options. Weather Clim. Extrem., High Level Meeting on National Drought Policy 3, 67-79. https://doi.org/10.1016/j.wace.2014.04.004

Témez, J., 1977. Modelo matemático de transformación "precipitación - escorrentía." Asociación de Investigación Industrial Eléctrica ASINEL. Madrid: 39.

Thornthwaite, C.W., 1948. An approach toward a rational classification of climate. Geogr. Rev. 38, 55-94.

Trenberth, K.E., Fasullo, J.T., Shepherd, T.G., 2015. Attribution of climate extreme events. Nat. Clim. Change 5, 725. https://doi.org/10.1038/nclimate2657

van der Schrier, G., Briffa, K.R., Jones, P.D., Osborn, T.J., 2006a. Summer Moisture Variability across Europe. J. Clim. 19, 2818-2834. https://doi.org/10.1175/JCLI3734.1

van der Schrier, G., Briffa, K.R., Osborn, T.J., Cook, E.R., 2006b. Summer moisture availability across North America. J. Geophys. Res. Atmospheres 111, D11102. https://doi.org/10.1029/2005JD006745

van der Schrier, G., Efthymiadis, D., Briffa, K.R., Jones, P.D., 2007. European Alpine moisture variability for 1800-2003. Int. J. Climatol. 27, 415-427. https://doi.org/10.1002/joc.1411

Van Rooy, M.P., 1965. A rainfall anomaly index independent of time and space. Notos $14,43-48$.

Vargas, G., Rutllant, J., Ortlieb, L., 2006. ENSO tropical-extratropical climate teleconnections and mechanisms for Holocene debris flows along the hyperarid coast of western South America $\left(17^{\circ}-24^{\circ}\right.$ S). Earth Planet. Sci. Lett. 249, 467483. https://doi.org/10.1016/j.eps1.2006.07.022

Verbist, K., Robertson, A.W., Cornelis, W.M., Gabriels, D., 2010. Seasonal Predictability of Daily Rainfall Characteristics in Central Northern Chile for 
Dry-Land Management. J. Appl. Meteorol. Climatol. 49, 1938-1955. https://doi.org/10.1175/2010JAMC2372.1

Vicente $\square$ Serrano, López $\square$ Moreno Juan I., Gimeno Luis, Nieto Raquel, Morán $\square$ Tejeda Enrique, Lorenzo $\square$ Lacruz Jorge, Beguería Santiago, Azorin $\square$ Molina Cesar, 2011. A multiscalar global evaluation of the impact of ENSO on droughts. J. Geophys. Res. Atmospheres 116. https://doi.org/10.1029/2011JD016039

Vicente-Serrano, S.M., Aguilar, E., Martínez, R., Martín-Hernández, N., AzorinMolina, C., Sanchez-Lorenzo, A., Kenawy, A.E., Tomás-Burguera, M., MoranTejeda, E., López-Moreno, J.I., Revuelto, J., Beguería, S., Nieto, J.J., Drumond, A., Gimeno, L., Nieto, R., 2016. The complex influence of ENSO on droughts in Ecuador. Clim. Dyn. 48, 405-427. https://doi.org/10.1007/s00382-016-3082-y

Vicente-Serrano, S.M., Beguería, S., López-Moreno, J.I., 2009. A Multiscalar Drought Index Sensitive to Global Warming: The Standardized Precipitation Evapotranspiration Index. J. Clim. 23, 1696-1718. https://doi.org/10.1175/2009JCLI2909.1

Wang, H., Kumar, A., 2015. Assessing the impact of ENSO on drought in the U.S. Southwest with NCEP climate model simulations. J. Hydrol. 526, 30-41. https://doi.org/10.1016/j.jhydrol.2014.12.012

Weghorst, K., 1996. The reclamation drought index: Guidelines and practical applications, in: North American Water and Environment Congress \& Destructive Water. ASCE, pp. 637-642.

Wells, N., Goddard, S., Hayes, M.J., 2004. A Self-Calibrating Palmer Drought Severity Index. J. Clim. 17, 2335-2351. https://doi.org/10.1175/15200442(2004)017<2335:ASPDSI >2.0.CO;2

Wilhite, D., 1991. Drought Planning: A Process for State Government. JAWRA J. Am. Water Resour. Assoc. 27, 29-38. https://doi.org/10.1111/j.17521688.1991.tb03110.x

Wilhite, D., Hayes, M., Knutson, C., 2005. Drought Preparedness Planning: Building Institutional Capacity. Drought Water Crises Sci. Technol. Manag. Issues. https://doi.org/10.1201/9781420028386.ch5

Wilhite, D., Hayes, M., Knutson, C., Smith, K., 2000. Planning for Drought: Moving from Crisis to Risk Management. JAWRA J. Am. Water Resour. Assoc. 36, 697-710. https://doi.org/10.1111/j.1752-1688.2000.tb04299.x

Wilhite, D.A., Kumar, S., K, M.V., Wood, D.A., 1956-, 2000. Early warning systems for drought preparedness and drought management.

Wong, G., Lanen, H.A.J. van, Torfs, P.J.J.F., 2013. Probabilistic analysis of hydrological drought characteristics using meteorological drought. Hydrol. Sci. J. 58, 253-270. https://doi.org/10.1080/02626667.2012.753147

World Food Programme, 2011. Building Resilience: Bridging Food Security, Climate Change Adaptation and Disaster Risk Reduction.

Yuan, F., Yasuda, H., Berndtsson, R., Uvo, C.B., Zhang, L., Hao, Z., Wang, X., 2016. Regional sea-surface temperatures explain spatial and temporal variation of summer precipitation in the source region of the Yellow River. Hydrol. Sci. J. 61, 1383-1394. https://doi.org/10.1080/02626667.2015.1035658 
Zolotokrylin, A.N., Titkova, T.B., Brito-Castillo, L., 2016. Wet and dry patterns associated with ENSO events in the Sonoran Desert from, 2000-2015. J. Arid Environ. 134, 21-32. https://doi.org/10.1016/j.jaridenv.2016.06.014 